Bryn Mawr College

Scholarship, Research, and Creative Work at Bryn Mawr College

Classical and Near Eastern Archaeology Faculty

Research and Scholarship

Classical and Near Eastern Archaeology

2005

\title{
The Achaemenid Empire in South Asia and Recent Excavations in Akra in Northwest Pakistan
}

Peter Magee

Bryn Mawr College, pmagee@brynmawr.edu

Cameron Petrie

Robert Knox

Farid Khan

Ken Thomas

Let us know how access to this document benefits you.

Follow this and additional works at: http://repository.brynmawr.edu/arch_pubs

Part of the Classical Archaeology and Art History Commons, and the History of Art, Architecture, and Archaeology Commons

\section{Custom Citation}

Magee, Peter, Cameron Petrie, Richard Knox, Farid Khan, and Ken Thomas. 2005. The Achaemenid Empire in South Asia and Recent Excavations in Akra in Northwest Pakistan. American Journal of Archaeology 109:711-741.

This paper is posted at Scholarship, Research, and Creative Work at Bryn Mawr College. http://repository.brynmawr.edu/arch_pubs/82

For more information, please contact repository@brynmawr.edu. 


\title{
The Achaemenid Empire in South Asia and Recent Excavations in Akra in Northwest Pakistan
}

\author{
PETER MAGEE, CAMERON PETRIE, ROBERT KNOX, FARID KHAN, AND KEN THOMAS
}

\begin{abstract}
The impact of the Achaemenid annexation of northwestern Pakistan has remained a focus for archaeological research for more than a century. A lack of well-stratified settlements and a focus on artifacts that are not necessarily appropriate for assessing the effects of imperial control have until now obfuscated our understanding of this issue. In this article, we present the results of three seasons of excavations at Akra located in the North West Frontier Province of Pakistan. Although research was cut short in 2001 by global events, our preliminary results indicate that the relationship between urbanism, trade, and the Achaemenid annexation was considerably more complex than previously argued by scholars. Akra experienced rapid growth in settlement at the beginning of the first millennium B.C., several centuries before the Achaemenids ruled this area, and exhibited contacts with regions in both peninsular India and Central Asia during this time. When we are able to return to Pakistan, we hope to investigate further the causes of this settlement expansion and trade.*
\end{abstract}

\section{INTRODUCTION}

The Achaemenid capitals at Pasargadae, Persepolis, and Susa have traditionally provided the basis of our understanding of the archacology of the Achaemenid empire. However, in recent decades archaeologists and historians alike have turned their attention to the peripheries of the empire in search of evidence of how the Achaemenids ruled

\footnotetext{
* The authors would like to thank the following scholars who read over drafts of this paper and made many useful comments and corrections; any errors that remain are the responsibility of the authors: Professor Dan Potts (Sydney), Professor James Wright (Bryn Mawr), Professor Stephanie Dalley (Oxford), and Professor Derek Kennet (Durham). The fieldwork that provided the data on which this paper is based would not have been possible without the financial assistance of the Australian Research Council, British Museum, Society for South Asian Studies (British Academy), Australian Institute of Nuclear Science and Engineering, and the University of Sydney. Without the assistance of numerous officials in Pakistan, fieldwork in Bannu would not have been possible. We would like to thank current and previous directors-general of archaeology and the many government officials in Bannu who facilitated our stay there.

${ }^{1}$ E.g., Sancisi-Weerdenburg and Kuhrt 1991; Summers 1993, 85-108; Dusinberre 1999, 73-102.

${ }^{2}$ E.g., Stern 1982.

${ }^{3}$ E.g., Sancisi-Weerdenburg and Kuhrt 1991.
}

subject peoples. A significant proportion of this research has been carried out on the regions that border the classical world, in particular Anatolia, ${ }^{1}$ the Levant, ${ }^{2}$ and Egypt. ${ }^{3}$ In contrast, the far eastern extent of the empire, which is encompassed by the borders of modern-day Pakistan and Afghanistan, has received less attention. In this paper, we present data from new excavations in northwest Pakistan that provide fresh insight into indigenous settlements in this region during and also prior to the period of Achaemenid annexation (fig. 1).

Royal inscriptions, edicts, and administrative texts dating from the reign of Darius onward indicate that there were three provinces located along the eastern frontier of the Achaemenid empire in what is today South Asia: Gandara, Thatagus, and Hindush. ${ }^{4}$ Toponyms, derivatives, and derivative ethnic designations also appear in the descriptions of the empire and its inhabitants recorded by a number of contemporary and later classical authors, including Herodotus, Arrian, and Quintus Curtius. ${ }^{5}$

The commemorative Behistun inscription, which was carved between ca. 520 and 518 B.C., ${ }^{6}$ lists Gandara and Thatagus among the provinces that Darius inherited when he seized the throne in 522 B.C. ${ }^{7}$ Thatagus also is listed as one of the provinces that rose up against the new $\mathrm{king}^{8}$ and was the loca-

\footnotetext{
${ }^{4}$ Vogelsang 1990, 97-102. For a comprehensive review, see Vogelsang 1992, 94-179.

${ }^{5}$ E.g., Sattagydia and India in Herodotus (3.89-95 [de Selincourt 1972]); India in Arrian (Anabasis 3.8.3-4, 3.28.1, and Indica [Brunt 2000, 2004]), and Quintus Curtius (4.12.9, 9.7.14 [Rolfe 1976]); Sattagydians, Gandharians, and Indians in Herodotus (3.98-105, $7.61 \mathrm{ff}$. [de Selincourt 1972]); and various types of Indians in Arrian (3.8.3-4. 3.28.1 [Brunt 2004]) and Quintus Curtius (4.12.9, 9.7.14 [Rolfe 1976]). For a comprehensive review of the relevant classical sources, see Vogelsang 1992, 180-244.

${ }^{6}$ Schmidt 1990, 299-300.

${ }^{7}$ Inscription of Darius I at Bisutum (hereafter DB), sec. 6, 1.12-17; Kent 1953, 117-9; Lecoq 1997, 187-214. This dating for Darius' accession follows the chronology outlined in Vogelsang 1986, 130; 1992, 122; 1998, 197.

${ }^{8} \mathrm{DB}$, sec. 20, 2.5-8, Kent 1953, 121-3. The details of Darius' accession have been extensively discussed; for recent assessments, see Vogelsang (1998, with references). For a provocative assessment of the ethnicity of Cyrus, see Potts (forthcoming).
} 


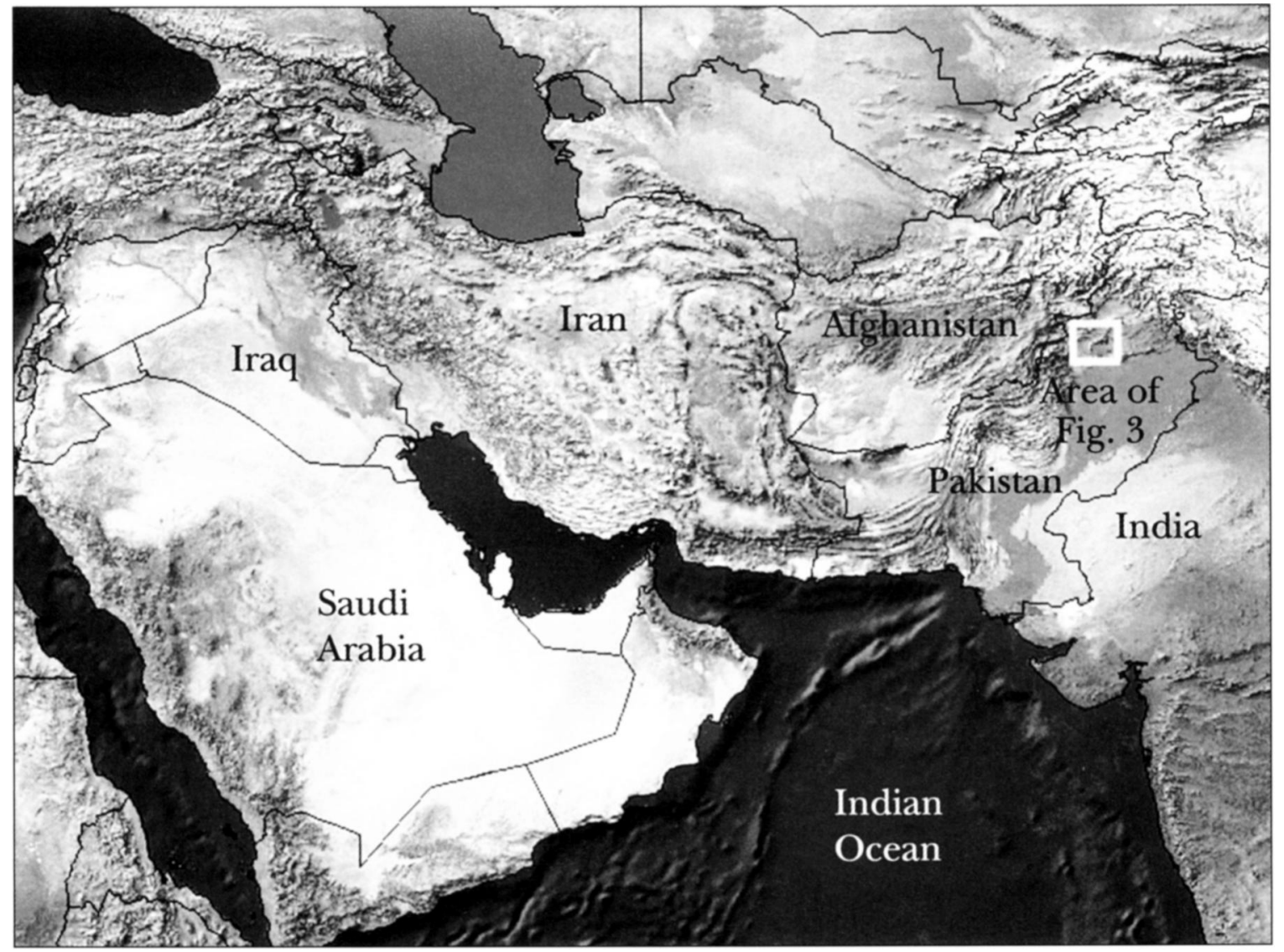

Fig. 1. Map of the Near East and South Asia. (Archaeological Computing Laboratory, University of Sydney)

tion of one of the three battles in the ensuing campaign against rebellious forces in the eastern provinces of the empire. ${ }^{9}$ However, the date of the initial annexation of Gandara and Thatagus is not certain. Recent assessments of the classical sources that relate Cyrus' expedition to Central Asia agree that he marched through Arachosia in southern Afghanistan, destroyed the city of Capisa (modern Begram), and then campaigned into Bactria between 539 and 530 B.C., when he died somewhere in the northeast of his newly expanded empire. ${ }^{10}$ The arrangement of the provinces in a number of Darius' royal inscriptions has been taken to indicate close

\footnotetext{
${ }^{9}$ Fleming 1982; Bivar 1988, 200; Vogelsang 1990, 100; 1992, 127-9. Discussed further below.

${ }^{10}$ Particularly Herodotus $(1.169,1.201-16$ [de Selincourt 1972]) but also Pliny (6, 24.92 [Rackham 1989]), Arrian (3.27.4 [Brunt 2004]), and Quintus Curtius (7.3.1 [Rolfe 1976]). See Francfort (1988, 170), Bivar (1988, 198-90), and Vogelsang (1992, 187-9), who list other sources. In contrast, Briant (2002, 38-40) maintains the order presented by Herodotus, implying that Cyrus campaigned to Central Asia before and after his victory in Babylon in 539 B.C.

${ }^{11}$ Vogelsang 1990, 99-100. Discussed further below.
}

relationships between Baxtrish (Bactria) and Gandara, ${ }^{11}$ and between Harauvatish (Arachosia) and Thatagus, ${ }^{12}$ which might mean that Gandara and Thatagus were annexed when Cyrus secured Arachosia and Bactria. Whether or not this is the case, Darius considered them to be part of his empire in 522 B.C.

It is generally supposed that Hindush is analogous with modern Sind, ${ }^{13}$ although there are no excavated remains that support this suggestion. ${ }^{14}$ This province is not mentioned in the Behistun inscription, but it does appear on all but one of Darius' other surviving inscriptions, ${ }^{15}$ including two

\footnotetext{
${ }^{12}$ Vogelsang 1985, 79-80; 1990, 100; 1992, 110-5, 129. Discussed further below.

${ }^{13}$ Reviewed in Bivar (1988, 202-4), where Taxila is proposed as a possible alternative, although the route of Scylax that is reconstructed does not pass Taxila. See also Vogelsang 1990, 101-2.

${ }^{14}$ Although there are significant Iron Age remains at Pirak in Baluchistan, the latest occupation phase (period III) has been dated to ca. 1100-800 B.C. (Jarrige and Santoni 1979, 12-3; Vogelsang 1985, 75-7).

${ }^{15}$ Kent 1953, DH 147, DNa 137-138, DPe 136, DPh 136-
} 
of the so-called foundation charters from Susa that do not mention either Gandara or Thatagus. ${ }^{16}$ Hindush appears with Thatagus among the 24 "fortress cartouches" inscribed on either side of the base of a statue of Darius, recovered at Susa in $1972,{ }^{17}$ and both are also represented on the socalled canal stelae from Egypt. ${ }^{18}$ Bivar has suggested that Hindush was annexed in 515 B.C., following the reconnaissance of the Indus River by Scylax of Caryanda undertaken in 517 B.C. ${ }^{19}$

The names for eastern provinces and their related ethnic designations also appear in several of the ration disbursement documents in the Persepolis Fortification (PF) text corpus (509-496 B.C.), which among other things typically lists the name of the traveler, the route, and the person who authorized the payment. ${ }^{20}$ The most regularly appearing toponyms from the eastern empire are Harauvatish (Arachosia) and Hindush, while Gandara is listed twice and Thatagus is completely absent. ${ }^{21}$ The one documented journey from Gandara to Susa (PF1358) was made via Harauvatish under the authority of an official there named Bakabadush who also authorized journeys from other areas. ${ }^{22}$ This has led to the suggestion that a route from Gandara to southwest Iran via the oasis of modern Kandahar was in common use. ${ }^{23}$ Although there are 16 separate documents that mention Hindush and/or Indians, ${ }^{24}$ only one relating to travel originating in Hindush was authorized by an official who may have resided there (PF1552).$^{25}$ Significantly, none of the

137, DSe 141-142, DSf 142-144, DSm 145; also Lecoq 1997, DH 218-219, DNa 219-221, DNe 225-226, DPe 228, DPh 230, DSe 232-234, DSf 234-237, DSm 239, DSv 242, DSz 243-245.

${ }^{16}$ Specifically DSf, Kent 1953, 142-4; Lecoq 1997, 234-7; DSz, Lecoq 1997, 243-5. These foundation charters list Hindush and Arachosia as suppliers of ivory, and because elephants are not known in historical Arachosia, Vogelsang has suggested that it acted as an emporium for the Indian ivory trade (Vogelsang 1985, 81; 1987, 186; 1992, 132).

${ }^{17}$ Stronach 1972, 241-3; Roaf 1974, 116, 145-7. There is no cartouche for Gandara.

${ }^{18}$ Roaf 1974, 79-84; Vogelsang 1992, 105.

${ }^{19}$ Bivar 1988, 201-3 (after Herodotus 4.44). See also Vogelsang 1990, 101-4.

${ }^{20}$ Vogelsang 1990, 101 (after Hallock 1969, 6). Bivar makes the assumption that authority to travel was being given by the satraps of the provinces in which the journeys originated (Bivar $1988,206-7)$. In the instance where the journey from Gandara was authorized by the satrap of Arachosia (PF1358), he suggests that the permit was being renewed (Bivar 1988, 205).

${ }^{21}$ Vogelsang 1990, 101. The lack of documents that mention Thatagus is only somewhat ameliorated by three texts that refer to Sa-da-ku-is, "the Sattagydian" (PF789, 2018, 2020), who was responsible for distributing agricultural produce at Shiraz (Bivar 1988, 208 [after Hallock 1969, 233, 622-4]).

${ }^{22}$ Bakabadush authorized travel from Arachosia, Gandara, journeys to or from Hindush appears to have been authorized in Harauvatish, suggesting that they may have been made via another route, possibly east through Baluchistan to Carmania. ${ }^{26}$ While this group of documents as a whole provides an often intimate view of the movement of individuals and groups to and from the east of the Achaemenid empire and of the routes that were being used, it is difficult to establish the significance of the paucity of documents related to Gandara and Thatagus. It may indicate that there was little movement between these two eastern provinces and the western centers at this time, but it could also reflect differential document survival.

Representatives of Gandara, Thatagus, and/or Hindush are depicted as delegates bringing gifts to the king on the Apadana staircases, and as throne/dais bearers on the Tripylon and Hall of One Hundred Columns reliefs at Persepolis. ${ }^{27}$ They also appear on the reliefs that decorate the exterior facades of the tombs of Darius and of each subsequent Achaemenid king at Naqsh-i Rustam and Persepolis, ${ }^{28}$ with the exception of the tomb of Darius III, which was unfinished when he was defeated by Alexander at Gaugamela in 331 B.C., and remained so after his death. ${ }^{29}$ The representatives of Gandara, Thatagus, and Hindush in each instance are characterized by their loincloths, sandals, and exposed upper body, which distinguish them from the representatives of other eastern provinces such as Bactria and Arachosia. ${ }^{30}$

and Barrikana, also in southern Afghanistan (Vogelsang 1990, 101). Bivar $(1988,205)$ suggests he was the satrap of Arachosia.

${ }^{23}$ Vogelsang 1985, 82-7; 1990, 101.

${ }^{24}$ Summarized in Vogelsang 1992, 167-9, table 12.

${ }^{25}$ This official was named Parnaka (Hallock 1969, 434; Vogelsang 1992, 167). PF1425 and 1529 refer to Indians being authorized by a certain Irdubama, who also authorized three other journeys (PF1362, 1491, 2051) leading Bivar to suggest that he was satrap of Hindush (Bivar 1988, 206-7).

${ }^{26}$ Vogelsang 1990, 102. This is noteworthy in light of the suggestion that Arachosia acted as an emporium for the Indian ivory trade (see supra n. 16; Vogelsang 1985, 81; 1987, $186 ; 1992,132$ ).

${ }^{27}$ Schmidt 1953, 82-90, 116-20, 134-7; Roaf 1974, 84-92; $1983,1-164$. The ethnic identification of the individuals and groups from the east is reviewed in Vogelsang (1992, 147-51). It is notable that at least one Indian representative or delegation is not depicted in each instance.

${ }^{28}$ Schmidt 1970, 77-118, pls. 39-52. The ethnic identification of individuals and groups from the east is reviewed in Vogelsang (1992, 135-43). Representatives of Gandara, Thatagus, and Hindush are shown on each tomb.

${ }^{29}$ Schmidt 1970, 107, pls. 76-79.

${ }^{30}$ Reviewed in Vogelsang 1992, 140-3; 1990, 98. The delegates from Maka will not be discussed here. 
The appearance of the representatives of Gandara, Thatagus, and Hindush on each royal tomb relief up to Artaxerxes III indicates that these provinces continued to be a part of the royal conception of the empire until at least 338 B.C., less than 10 years before Alexander's victory at Gaugamela. The maintenance of fealty with the Achaemenid king beyond this date is suggested by Arrian's description of the army of Darius III at Gaugamela, where the king is said to have "obtained the help of those Indians who bordered on the Bactrians, together with the Bactrians and Sogdianians themselves, all under the command of Bessus, the satrap of Bactria."31 Arrian then notes, "Barsentes, satrap of the Arachotians, led both the Arachotians and the Indian hill-men, as they were called." ${ }^{32} \mathrm{Al}-$ though Arrian does not use the more specific ethnic determiners used by Herodotus, if the evidence of a relationship between Bactria and Gandara is taken into consideration, then it is likely that the Indians bordering the Bactrians at Gaugamela were troops from Gandara. ${ }^{33}$ The Indian hill-men were thus presumably from either Thatagus or Hindush, depending on the perceived boundaries of those provinces.

There has been some debate about the nature of Achaemenid administration over the eastern provinces, using Achaemenid and classical sources. What is clear is that both are harmonious in referring to the existence of satraps in Bactria and Arachosia (Harauvatish), whereas at no point does either refer to satraps in Gandara, Thatagus, or Hindush. ${ }^{34}$ However, the chroniclers of Alexander make it clear that there were rulers and/or official personages in the far eastern provinces in the late fourth century B.C. ${ }^{35}$ Vogelsang has argued that the sources indicate the existence of a stepped admin-

\footnotetext{
${ }^{31}$ Arrian Anabasis 3.8.3 [Brunt 2004]; Vogelsang 1992, 2213; Briant 2002, 756.

${ }^{32}$ Arrian Anabasis 3.8.4 [Brunt 2004]; Vogelsang 1992, 2213; Briant 2002, 756.

${ }^{33}$ Vogelsang 1992, 222-3.

${ }^{34}$ E.g., DB, sec. 38, 3.10-19, sec. 45, 3.54-64; Kent 1953; Arrian 3.8.3-4, 3.25.8 (Brunt 2004). See also the discussion in Vogelsang 1992, 169-73.

${ }^{35}$ E.g., when Alexander marches toward India, he is met by Taxiles' and the Indian hyparchs (ün $\alpha \rho X o \mathrm{)}$ ), or princes west of the Indus (Arrian 4.22.6 [Brunt 2004]), who are considered both rulers in their own right and de facto subjects of the Great King (Bosworth 1995, 147-8; Vogelsang 1992, 236; Briant 2002, $748,756-7)$. The use of the title "hyparchs" has the connotation of subordination, and could emphasize both Alexander's perceived self-justification and provide an indication of the nature of their relationship to the Achaemenid king (Bosworth 1995, 147-8). Bosworth has suggested that when Alexander seized control of the Achaemenid empire, he may have con-
}

istration with four levels of control: the king, the provincial governor, the local potentate, and the local masses. ${ }^{36}$ As such, Arachosia appears to have been an important administrative center, with a satrap who had influence over the neighboring provinces to the east, particularly Thatagus. ${ }^{37} \mathrm{~A}$ similar situation appears to have existed between Bactria and Gandara, ${ }^{38}$ which is supported by the fact that there are no clear references to Achaemenid officials in the Indus Valley in the ancient Indian literature, but there are references to Bactrians and Kambojas. ${ }^{39}$ The satraps in Bactria and Arachosia are first mentioned in the Behistun inscription, suggesting that this system operated at least from $520-518$ B.C. ${ }^{40}$ and the description of the army of Darius III indicates that it was maintained until the empire was subsumed by Alexander in 330 B.C. ${ }^{41}$

From the commencement of archaeological research in what is today modern Pakistan, attempts were made to discover Achaemenid occupation in the region and to identify relevant place-names mentioned in the Achaemenid and classical sources. This was particularly so for the province of Gandara, due to its importance in both the Achaemenid and the later Kushan periods. As early as 1863, Sir Alexander Cunningham proposed that Charsadda, which is situated in the Peshawar Valley, was the location of ancient Pushkalavati (fig. 2). ${ }^{42}$ This Sanskrit name became the Greek Peukelaotis, Peukelaitis, and Peukala used by Arrian, Strabo, and Pliny, respectively. ${ }^{43}$ Sir John Marshall confirmed Cunningham's identification in 1903 when he recovered an inscription from Ghaz Dheri, $1.6 \mathrm{~km}$ from Charsadda, which contained the phrase "Puskhala visae" or "in the district of Puskala." ${ }^{44}$ The significance of Cunningham's pioneering identification is emphasized by the fact that it was made nearly 60

sidered the Indian rulers to be, by right, his subjects; and in his invasion, he was effectively reaffirming control over his proper vassals. In apparent contrast to his Achaemenid predecessors, he made a point of appointing satraps throughout the conquered Indian territories, either making new appointments, or reappointing previous rulers (e.g., Arrian 5.29.4, 6.16.3 [Brunt 2004]).

${ }^{36}$ Vogelsang 1985, 87-91; 1992, 227, and esp. 313-5.

${ }^{37}$ Vogelsang 1985, 87-91; 1990, 100; 1992, 172-3, 227, 313-5.

${ }^{38}$ Vogelsang 1985, 87-91; 1990, 99-100; 1992, 178-9, 3135; Briant 2002, 746.

${ }^{39}$ Vogelsang 1987, 187 (after Witzel 1980); Bivar 1988, 199.

${ }^{40}$ E.g., DB, sec. 38, 3.10-19, sec. 45, 3.54-64; Kent 1953.

${ }^{41}$ Arrian 3.8.3-4 (Brunt 2004); Vogelsang 1992, 314.

${ }^{42}$ Cunningham 1871, 89.

${ }^{43}$ Arrian Anabasis 4.22, 4.28, and Indica 4.11 (Brunt 2000, 2004); Strabo 15.1.27 (Jones 1976); Pliny 4.21.62 (after Wheeler 1962, 3).

${ }^{44}$ Marshall 1904, 176. 


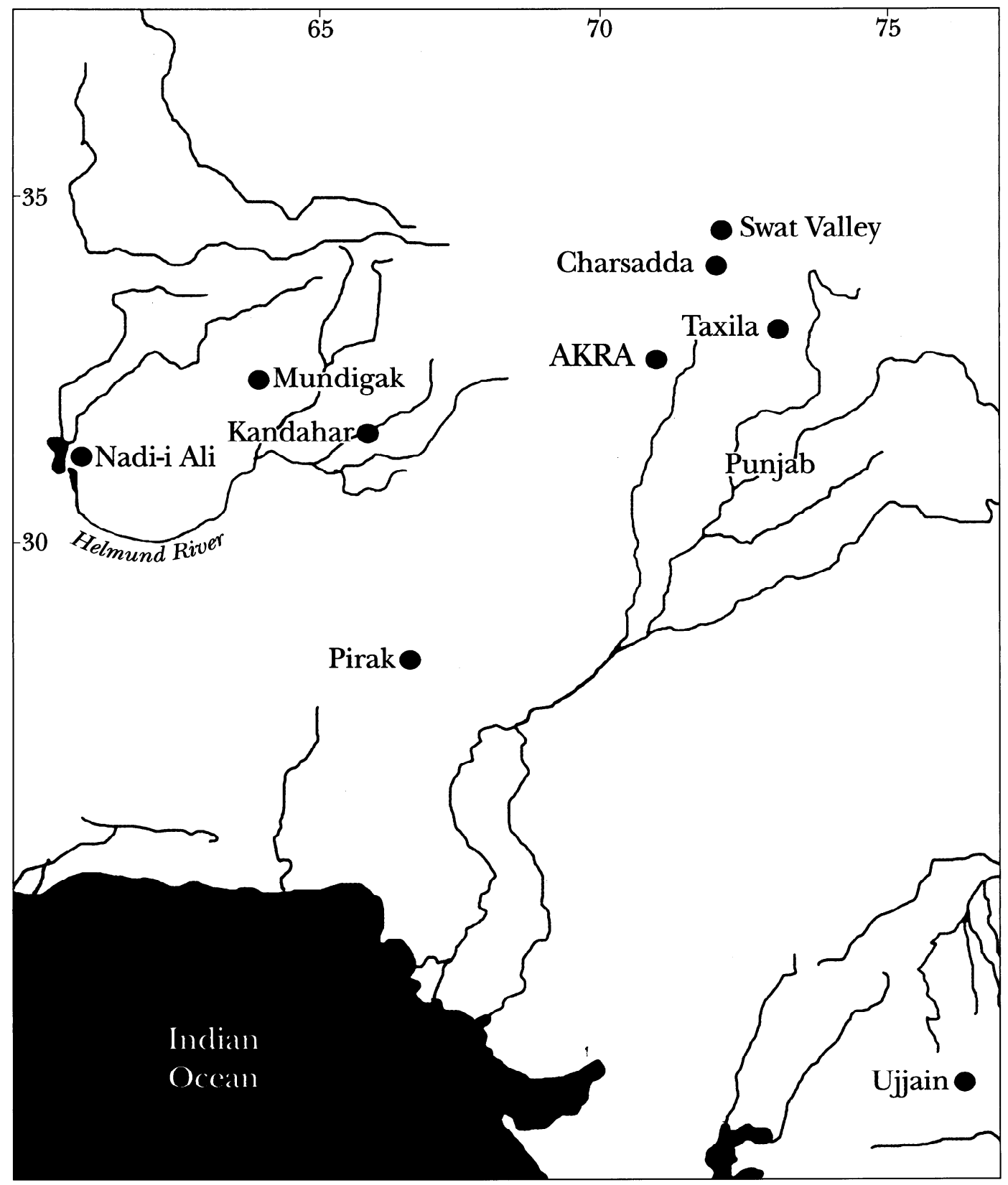

Fig. 2. Map of Pakistan, northern India, and Afghanistan, showing main Iron Age sites

years before the publication of $\mathrm{H}$. Weissbach's magisterial Keilinschriften der Achämeniden of 1911, which led to so much research on the territories and provincial administration of the empire.

Since the 1950s, archaeological teams have conducted more systematic excavations at sites in northwest Pakistan that are relevant to the time frame of the Achaemenid conquest. Sir Mortimer Wheeler's excavations at the Bala Hissar at Charsadda in 1958

\footnotetext{
${ }^{45}$ Wheeler 1962, 13, 33.

${ }^{46}$ Dittmann 1984, 155-93.
}

provided the first well-stratified archaeological sequence in the region. ${ }^{45}$ Although he initially proposed that there was no substantial occupation at the site before the Achaemenid period, reanalysis of Wheeler's sequence ${ }^{46}$ and renewed excavations at the site ${ }^{47}$ have shown that it was actually founded in the mid second millennium B.C., and that it is the only site in the Peshawar Valley with an unbroken sequence of occupation from ca. 1400 to 50

${ }^{47}$ Ali et al. 1998, 1-34. 
B.C. ${ }^{48}$ Recent excavations at the Bala Hissar have aimed at confirming the timing of the site's foundation $^{49}$ and have produced little in the way of new results that are directly relevant to the Achaemenid period.

To the north of Charsadda, in the Swat Valley, Italian and Pakistani archaeologists have been conducting research since the late 1950s. The excavations at a number of necropoleis, including Kherai, ${ }^{50}$ Loebanr, Katelai, Butkara, ${ }^{51}$ and Timargarha,${ }^{52}$ have revealed a sequence of cultural material that the Italians have organized into numbered phases (Swat $1-7) .{ }^{53}$ Dani has labeled this assemblage the Gandharan Grave Culture. ${ }^{54}$ The investigation of affiliated settlement sites such as Aligrama and Ghaligai ${ }^{55}$ has contextualized this grave sequence by revealing associated domestic assemblages. There is general agreement that the Swat/ Gandharan grave sequence as a whole can be dated from the mid to late second millennium to the end of the first millennium B.C. However, there is controversy over the relative dating of the phases and the absolute dating of the entire sequence, and no single site has been excavated that provides a complete sequence. ${ }^{56}$

The excavations at the site of Bir-kot-ghwandai had the potential to anchor the Swat sequence in a specific Achaemenid historical context. Sir Aurel Stein was the first to identify Bir-kot-ghwandai as Bazira, ${ }^{57}$ a city that, according to Arrian, was captured and fortified by the Macedonians during Alexander's conquest of Swat. ${ }^{58}$ Excavations began at the site with the aim of establishing the validity of Stein's identification, ${ }^{59}$ and Callieri thought he was initially able to provide validation due to the discovery of a fortification wall during excavations. ${ }^{60}$ However, on the basis of numismatic finds, it has been established that this wall could not have been constructed until the Indo-Greek period in the second to first centuries B.C. ${ }^{61}$ In fact, Olivieri has gone so far as to say, "the information provided by the excavation to date is not yet sufficient to prove

\footnotetext{
${ }^{48}$ Dittmann 1984, 159, 193.

${ }^{49}$ Ali et al. 1998, 1-34.

${ }^{50}$ Stacul 1966b, 261-74.

${ }^{51}$ Salvatori 1975, 333-51.

${ }^{52}$ Dani 1967, 22-40.

${ }^{53}$ Tusa 1979, 675-90.

${ }^{54}$ Dani 1967, 22-40.

${ }^{55}$ Stacul 1967, 9-43.

${ }^{56}$ Cf. Stacul 1966a, 37-79; Dani 1967, 24-40.

${ }^{57}$ Stein 1929b, 40, 47.

${ }^{58}$ Arrian 4.27-8 (Brunt 2000).

${ }^{59}$ Filigenzi and Stacul 1985, 436.
}

categorically that the archaeological site of Bir-kotghwandai actually corresponds to the Bazira mentioned by Alexander's historians." 62

As such, the excavations at settlement sites and cemeteries in northwest Pakistan have exposed sequences of material remains that can be dated from the mid to late second millennium to the late first millennium B.C. However, while the question of the Achaemenid and/or Hellenistic presence has remained one of the main foci of this research, there is little doubt that we are no closer to understanding the impact of these imperial powers than we were 40 years ago. In the first instance, the identification of Achaemenid archaeological horizons at sites in northwest Pakistan has been significantly affected by the unstratified nature of many of the cemetery excavations in the Swat Valley; the lack of consensus over the relative sequence of the material from the settlements and graves; and the problems associated with the absolute chronology of the sequence at Charsadda. The dearth of comparative Achaemenid-period material in areas immediately to the west has exacerbated this problem. The only major excavated site in Afghanistan with evidence for Achaemenid occupation is Kandahar, which is situated almost $500 \mathrm{~km}$ to the east of the Indus River, and has been proposed as the possible location of the capital of the Achaemenid province of Arachosia (fig. 2) ${ }^{63}$ Even at this major site, however, there are conflicting interpretations of the chronology of the Iron Age and Achaemenid-period deposits. ${ }^{64}$ Scholars have acknowledged these problems. The most comprehensive review of these issues led Dittmann to conclude, "what is perfectly clear is that the sequence of the 1st millennium B.C. in northern Pakistan needs much more study. . . . My hope is that, in the future, Pakistan archaeology will follow the pioneering work of Wheeler, Dani and Stacul in order to elucidate one of the most interesting periods in Pakistan's history, namely the Iron Age." ${ }^{65}$

In the absence of any clearly defined archaeological contexts that can be positioned in relation

\footnotetext{
${ }^{60}$ Callieri 1990, 676; Callieri et al. 1990, 164; see also Callieri et al. 1992.

${ }^{61}$ Olivieri 1996, 50 .

${ }^{62}$ Olivieri 1996, 50.

${ }^{63}$ McNicoll and Ball (1996, 392-4) indicate that Mundigak (period IV) is another possible candidate, while Helms (1997, 91-2) argues that there is cause to doubt that Kandahar is the capital.

${ }^{64}$ E.g., compare the chronology and conclusions presented in McNicoll and Ball (1996, xvii, 392-4) with those in Helms (1997, 91-2).

${ }^{65}$ Dittmann 1984, 191.
} 
to the historical narrative, interpretations of the effects of Achaemenid annexation, therefore, have relied on either generalized theories concerning the beneficial impacts of colonial or imperial activity in South Asia or the identification of artifacts that might confirm a physical Persian presence. For an example of the former approach we need not look any further than Wheeler's introduction to his volume on Charsadda, where he says:

From the decline of the prehistoric Indus Civilisation of the third and second millennia until the advent of the Achaemenid kings in the middle of the sixth century B.C., it may be inferred and assumed that these regions were the battlefields of jealous local regimes; a condition which in the time of Alexander still subsisted in some measure east of the Indus. To the worst abuses of this inter-regional rivalry the strong arm of the Persian Empire set a term. Safe communications were amongst the Imperial blessings and long-distance trafficking became at last secure and profitable. Commercial cities such as those just mentioned were the economic response, whether newly founded or newly enlarged. There is in fact no hint that Begram or Charsad (d)a or Taxila existed appreciably before the extension of Persian power across the Hindu Kush in early Achaemenid times. ${ }^{66}$

Wheeler had few external indicators for the chronology of the Bala Hissar, and so the assumptions concerning the benefits of empire undoubtedly played a significant part in his interpretation of the site's history. Furthermore, given the critical role that he played in the colonial authority in South Asia,${ }^{67}$ it is also arguable that Wheeler's interpretation was as reflective of his perceptions of the benefits of British rule in South Asia as it was an important reading of the archaeological record.

Attempts to identify classes of objects that may serve as verification of an actual Persian military or bureaucratic presence have further obfuscated an understanding of the impact of imperial control. For example, the appearance of punch-marked coins at Taxila, ${ }^{68}$ the recognition of Aramaic as a known language in post-Achaemenid Mauryan inscriptions, ${ }^{69}$ and the influence of Achaemenid monumental sculpture on Mauryan palatial architecture $^{70}$ all have at various times been emphasized

\footnotetext{
${ }^{66}$ Wheeler 1962, 5 .

${ }^{67}$ Boast 2002, 165-70.

${ }^{68}$ E.g., Allchin $(1995,131)$, where it is commented that punch-marked coins "may be seen as almost the only substantial evidence of an Achaemenid presence in the early Bhir mound." Such an argument is indeed questionable given that there is no evidence to indicate that Taxila was necessarily part of the Achaemenid administrative network at this time. This is further emphasized in the most recent analysis of punchmarked coinage by Cribb $(1985,549)$, in which he argues that
}

as testimony to the influence of the Achaemenids. Such evidence is of questionable relevance in examining ancient imperialism because it provides no insight into indigenous responses to imperial strategies of control. More important, as noted by Sancisi-Weerdenburg, ${ }^{71}$ when such evidence is absent the empire is prone to be interpreted as weak, a possibly erroneous conclusion that takes no account of the multiplicity of strategies that centers can employ to subjugate and integrate subject provinces. ${ }^{72}$ An alternative and more productive avenue is to examine the indigenous (and foreign) archaeological evidence that dates before and after such a conquest, to determine whether changing patterns of social and economic behavior coincide with imperial episodes. Many Old and New World studies have been characterized by such an approach. For example, the Upper Mantaro Archaeological Project in Peru focused on the manner in which production and subsistence was altered with the incorporation of this region into the Inca empire in the Wanka III period. By examining changes in technology, ceramic production, and alterations in subsistence strategies, ${ }^{73}$ the effects of imperial conquest were discernible. Similarly, Morrison and Sinopoli's analysis of agricultural production and tribute in the Vijayanagara empire in India illuminated the varied strategies employed in provincial areas to satisfy imperial economic policy. ${ }^{74}$

The project that forms the basis of this article has as its aim the elucidation of changes in economic and social structures across the time period in which northwest Pakistan is incorporated into the Achaemenid empire. We had hoped to focus on this issue by examining changes in settlement size and distribution, subsistence strategies, and shifts in ceramic production using compositional analysis; but recent global events have meant that the continued collection of data in the field has been temporarily suspended. Nonetheless, three seasons of excavation have provided fresh evidence for the chronology and socioeconomic configuration of settlement before and, to a lesser extent, during the Achaemenid annexation. The data suggest a

\footnotetext{
this coinage is not to be associated with the Achaemenids.

${ }^{69}$ Allchin 1995, 132-3.

${ }^{70}$ For the questionable influence of Achaemenid art on Mauryan palatial architecture, see Chakrabati 1997, 190-1.

${ }^{71}$ Sancisi-Weerdenburg 1990, 264.

${ }^{72}$ Sinopoli 1994, 169-72.

${ }^{73}$ Costin etal. 1989, 107-39; D'Altroy and Bishop 1990, 120 38; Hastorf 1990, 262-90.

${ }^{74}$ Morrison and Sinopoli 1992, 335-52.
} 
much more complex trajectory for settlement patterns in this part of South Asia than is implied in Wheeler's analysis. In particular, it is evident based on our excavations at Akra and surrounding sites in the Bannu Basin that the emergence of urbanism in this region was in no way linked to imperial episodes. We present this new evidence in the hope that it may both methodologically and substantively contribute to our understanding of the archaeology of the Achaemenid empire and late prehistoric South Asia.

\section{AKRA AND THE IRON AGE IN THE BANNU BASIN}

Since 1986, a research team currently made up of members from Bryn Mawr College, the British Museum, the Institute of Archaeology (University College London), the Pakistan Heritage Society, and the University of Oxford has been conducting archaeological research in the Bannu Basin, which lies south of Peshawar in the North West Frontier Province (fig. 3). The basin is a small, topographically defined region to the east of the Sulaiman Range, and is separated from the Gomal Plain in the south and the Indus River and plain to the east by a series of substantial ranges. ${ }^{75}$ This is a climatically marginal area, between western winter and eastern summer precipitation zones, and does not receive regular rainfall from either. It is, however, fed by a number of ephemeral streams that flow out of the various ranges, and by two perennial rivers, the Kurram and the Tochi, which flow from the Sulaiman Range and have created passes through the mountains between the eastern low- and western highlands. The ancient and modern settlements are concentrated in the northwestern part of the basin, in the area between the two perennial rivers. ${ }^{76}$

From 1986 until 1995 the Bannu Archaeological Project (BAP) focused on the survey, excavation, and analysis of a number of prehistoric sites that range in date from the Neolithic period to the Bronze Age, the most notable being Sheri Khan Tarakai. ${ }^{77}$ The research of the BAP has shown that local environmental conditions have had a particular effect on prehistoric subsistence strategies and the social and settlement systems in the region. ${ }^{78}$

\footnotetext{
${ }^{75}$ Hemphill and Kidwai 1973, pl. 5.

${ }^{76}$ Thomas and Knox 1994, 97.

${ }^{77}$ For reports on this work, see Khan et al. 1986, 83-90; 1987, 83-90; 1988, 99-148; 1989, 281-91; 1990, 241-7; 1991a; 1991b, 111-27; 1991c, 156-74; 2000d; Thomas and Knox 1994, 89-104; Thomas et al. 1997, 237-51.
}

Throughout the history of occupation, there are material signs of continuous contact with the hill areas to the west, and there are also indications of variable and intermittent contact with areas as diverse as Baluchistan, the Gomal, and the Indus to the south and east, and with various parts of Central Asia to the northwest and west. ${ }^{79}$

In 1995 the project turned its attention to the site of Ter Kala Dheri, located about $5 \mathrm{~km}$ to the south of Bannu city on the banks of an ephemeral stream known locally as the Lohra nullah (or stream).$^{80}$ This settlement appears to have once been quite large, and while it may have originally stretched along the bank of the nullah at a width of $400 \mathrm{~m}$, it is now almost entirely ruined by erosion and intentional destruction. ${ }^{81}$ Of the six trenches that were excavated, only two contained intact occupation deposits: trenches TKD-N and TKD-S2. Each of these revealed a distinct phase of occupation; TKD-N presented surface and pit deposits with an associated Neolithic ceramic assemblage comparable to material from Sheri Khan Tarakai. TKD-S2 revealed in situ floor deposits associated with a previously unknown assemblage of handmade ceramic forms, characterized by black-on-red geometric decoration on a brown ground. ${ }^{82}$ This distinctive ceramic material was aptly labeled Bannu black-on-red ware, and two radiocarbon determinations from the stratified layers containing this new assemblage indicated a possible date in the early first millennium B.C. ${ }^{83}$ The ceramic assemblage draws its closest parallels to the Iron Age assemblage from Margiana in Central Asia, and the excavations at Ter Kala Dheri were the first in the Bannu region with material dating to this period. Despite the significance of the finding, there were major limitations with the excavations at the site, particularly that it has been heavily disturbed and that the two preserved phases of occupation are separated by a considerable gap in time, indicating that there may not be an intact sequence of continuous occupation preserved at the site. However, the discovery of deposits containing the hitherto unknown phase of occupation drew the project's attention to the imposing mounds of Akra, located approximately $7 \mathrm{~km}$ south of Ter Kala Dheri and about $12 \mathrm{~km}$ south of Bannu. Previous surface surveys at Akra had

\footnotetext{
${ }^{78}$ E.g., Thomas 1986, 26-7.

${ }^{79}$ Thomas and Knox 1994.

${ }^{80}$ Khan et al. 2000d, 81-100.

${ }^{81}$ Khan et al. 2000d, 81.

${ }^{82}$ Khan et al. 2000d, 83, 86-9.

${ }^{83}$ Stuiver et al. 1998; Khan et al. 2000d, 89-91.
} 


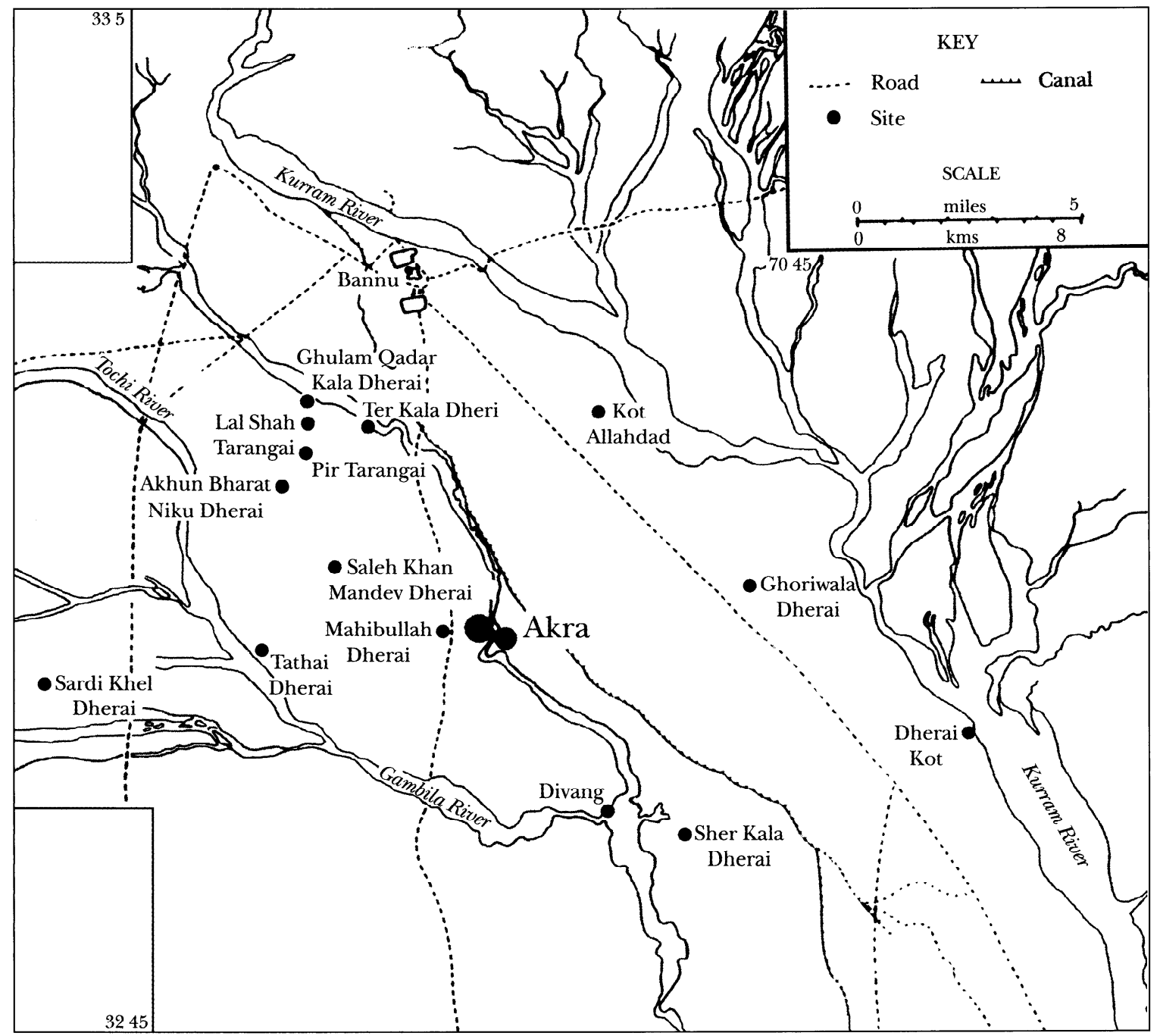

Fig. 3. Map of Bannu Basin, showing main Early Historic sites

shown that fragments of the newly observed Bannu black-on-red ware liberally covered the surface of parts of the site.

Akra is physically the most prominent site in the Bannu region and has been known to European visitors and scholars for more than 150 years. It attracted the attention of a number of military officers stationed in the district during the late 19th and early 20th centuries A.D., including Sir Herbert Edwardes and S.S. Thorburn. ${ }^{84}$ Sir Aurel Stein visited and photographed the site in $1905,{ }^{85}$ and Raverty, Gordon, Dani, and $\mathrm{Khan}^{86}$ all have described the site and/or aspects of its history. The

\footnotetext{
${ }^{84}$ Edwardes 1851; Thorburn 1876.

${ }^{85}$ Stein 1905.

${ }^{86}$ Raverty 1883; Gordon 1943, 136-95; Dani 1968, 250-64;
}

discovery of coins and numerous fine art objects there during the 19 th century in particular suggested to these scholars that the site was most important during the Historic period (ca. 250 B.C. to A.D. 1000). These discoveries coupled with the site's size led Stein to argue that Akra was the ancient capital of Bannu, and he drew attention to the records of the Chinese Buddhist pilgrims Faxian and Xuanzang who visited the Bannu region on their travels through the subcontinent in the fifth and seventh centuries A.D., respectively. ${ }^{87}$ Stein also made the prescient observation that the ample irrigation and remarkable fertility in the north-

Khan 1986, 183-95.

${ }^{87}$ Stein 1905, 7-10; 1929a, 14; Liu 1994, 196. 
west of the Bannu Basin bore a resemblance to the typical oases of eastern and western Turkestan in Central Asia. ${ }^{88}$

The preserved area of Akra now stands as a series of occupation mounds with interspersed agricultural fields. The mounds themselves are divided into two groups of unequal size by the Lohra nullah, which also flows past Ter Kala Dheri (fig. 4). That this stream is an ancient topographical feature is suggested by the immense alluvial deposits on either bank. Freshwater springs are found below the large mound on the right bank of the nullah and serve as important sources of water for modern inhabitants. It is probable that these are also an ancient feature of the landscape, and the abundant freshwater supply and the extremely rich alluvial soils would have provided an ideal environment for cereal and other cultivation. These ideas will be tested by continued paleoenvironmental studies that will be an integral part of our research program when we are able to renew our work at Akra.

\section{Surveys}

Between 1995 and 1998 three separate topographic surveys were carried out at Akra, covering the main mounded area of the site as well as other mounds in the surrounding area. In 1995 a brief theodolite survey revealed that at least 31.7 ha (78 acres) of the main mounded area were still preserved on both sides of the Lohra nullah. ${ }^{89}$ In 1996 this initial theodolite survey was extended beyond the main mounded area to the north, along the course of the nullah. It showed that an additional 48 ha of mounds and material scatters are still preserved on the right bank of the nullah, indicating that the total preserved area of Akra might be around 80 ha (fig. 5). ${ }^{90}$ While there can be no certainty about the precise chronological relationship between the outer mounds and the main mounded area, it is likely that at the time of its maximum Historic-period occupation, Akra was a sprawling urban site.

To further investigate the topography of the mounds, and to highlight areas that may be worthy of excavation, the entire main mounded area was surveyed three-dimensionally in 1998, using a Sokkia Set 5A Total Station and SDR 31 data logger. This survey included the establishment of a site datum and a precise site grid aligned to magnetic north. In total, 7,297 data points with abso-

\footnotetext{
${ }^{88}$ Stein $1905,6$.

${ }^{89}$ Khan et al. 2000d, 46.
}

lute heights were measured relative to an arbitrary site datum, ${ }^{91}$ which was used in the absence of a reliable survey benchmark at the site. The data obtained in the 1998 survey were converted into a digital elevation model that could be rotated and manipulated three-dimensionally, and was used to gain a clearer understanding of site formation processes, the extant archaeological remains, and the natural features of the site (fig. 6).

For ease of identification we have delineated two main archaeological zones at Akra, using the Lohra nullah as an arbitrary boundary. Area A, on the east side of the nullah, consists of a large mound that has been extensively damaged by modern digging (see fig. 4). The upper surface is now predominantly flat, but it is punctuated by several outcrops of deposits, the largest of which rises about $15 \mathrm{~m}$ above the preserved mound surface and about 35 $\mathrm{m}$ above the surrounding plain. On the west bank of the stream, the terrain consists of several mounds that have been damaged by leveling for modern fields and erosion caused by the course of the nullah (fig. 6). These mounds vary in size and height, and rise between 14 and $20 \mathrm{~m}$ above the surrounding plain.

\section{Excavations and Methodology}

In the initial reconnaissance of Akra in 1995, it was observed that fragments of the distinctive Bannu black-on-red ware like those found at Ter Kala Dheri were also visible on the surface of the mounds on the west bank of the nullah (area B). Between 1996 and 2000 excavations were carried out on three different mounds in area $B$ with the aims of confirming the early first millennium B.C. dates suggested for Bannu black-on-red ware at Ter Kala Dheri; defining the stratigraphic position of this ware in relation to other occupation at the site; and providing some data on the extent and size of the settlement during the first millennium B.C. (fig. 7 ). The excavations that have been carried out include a shallow sounding (Chigkamar mound [hereafter CGK]), a deep stratigraphic probe (Lohra mound), and an open area excavation (Hussaini Boi Ziarat Dherai [hereafter HBZD]).

In each area, excavations proceeded with the identification, delimitation, and removal of discrete stratigraphic units or loci, which were allocated unique locus numbers. Each locus was recorded on a separate data sheet, where the nature of the

\footnotetext{
${ }^{90}$ Khan et al. 2000d, 46.

${ }^{91}$ Set at $1,000 \mathrm{~m}$ above sea level.
} 


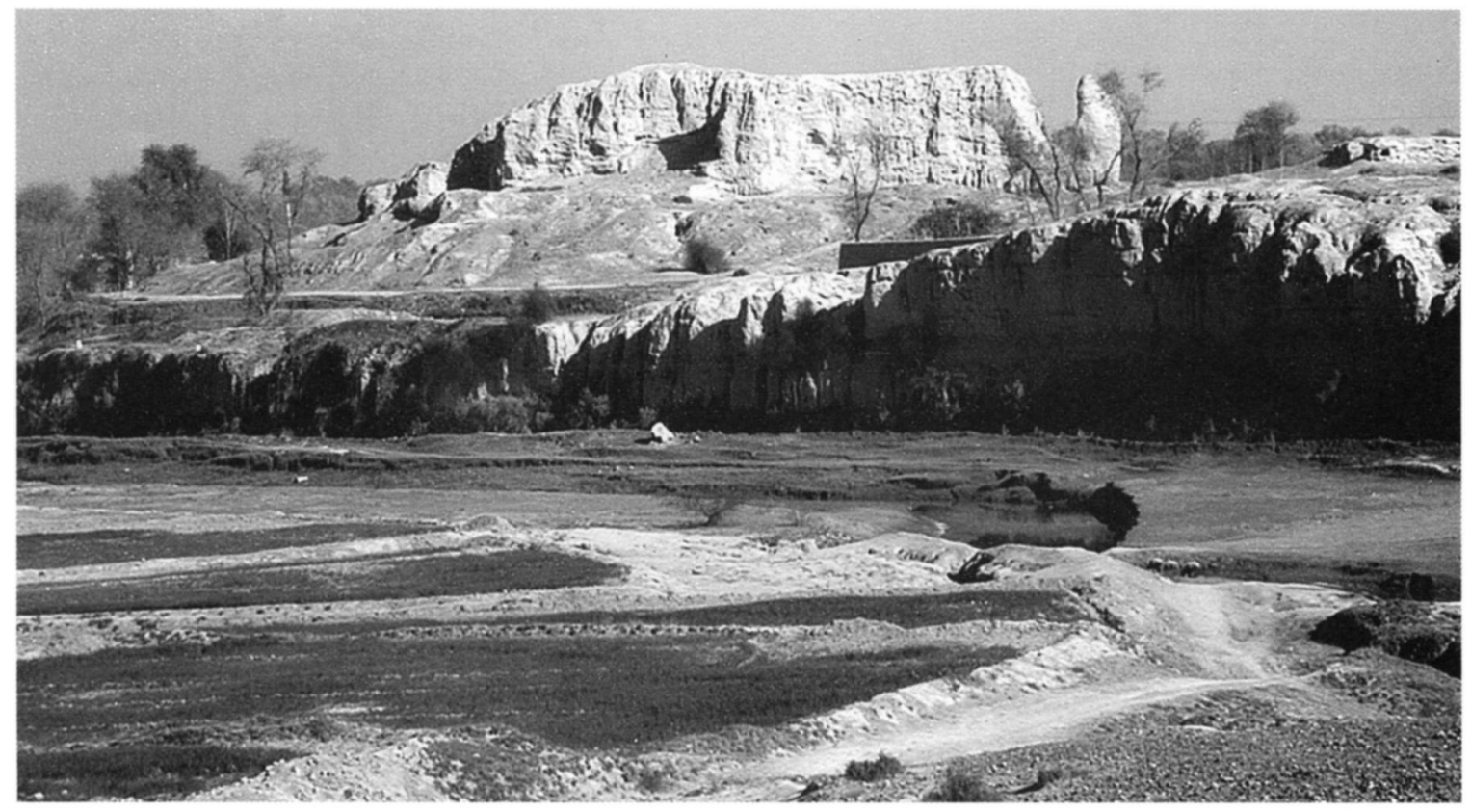

Fig. 4. View toward west of citadel in area A. Lohra nullah is in the foreground.

deposit was defined through the selection of relevant tick boxes and a written description. The location and extent of each locus was also drawn in plan, and digital photographs were taken of specific deposits. From floor surfaces, pits, and collapse debris, 10 or 20 soil samples were collected for flotation. All deposits below the surface topsoil were sieved with a $10-\mathrm{mm}$ screen, which is the only gauge locally available. All cultural material recovered from the sieve was collected, and the remaining soil matrix was discarded. Ceramic fragments, animal bone, small finds, and carbonized material were separated on site and were placed in clean plastic bags and labeled with the date, trench number, locus number, and a brief description. This cultural material was returned to the dig house, where the ceramic fragments were cleaned and sorted into diagnostic and nondiagnostic fragments, and registration was conducted. A considerable quantity of carbonized material was recovered, and readily visible pieces were removed using a cleaned trowel and placed into a new Ziploc ${ }^{\circledR}$ plastic bag, which was then labeled with an indelible pen. At the completion of excavations, groups of individual loci that relate to specific structural features, or could otherwise be shown to be contemporaneous, were attributed to individual phases.

CGK Mound Sounding. The surface of most of area $\mathrm{B}$ is littered with fragments of Bannu black-on-red ware. In 1996 a 4 × 4 m trench (trench 2) was positioned on the slope of a large mound at the north- ern edge of area B. Excavations revealed a hardened earth/mud floor approximately $45 \mathrm{~cm}$ below the present ground surface. Above this floor thick habitation deposits, including many ash lenses, were preserved. A complete vessel with one functional fan spout and one false fan spout was recovered sitting on the earth/mud floor, along with fragments of Bannu black-on-red ware vessels (fig. 8). No other architectural features were observed, and excavations were halted at this point.

Lohra Mound. This significant mound, which lies in the south of area B, was excavated in 1996, 1998, and 2000. In 1996 trench 1 was opened across an area stretching from the highest point of the mound to the edge of its flattened upper surface, and revealed two boulder-constructed buildings: one structure visibly extended from the west baulk and another was evident in the south baulk. Although badly damaged in some places, the walls were clearly constructed from large river boulders, the upper courses of which were laid as "stretchers" while the lowest courses were "headers" (fig. 9). The stonefaced walls were filled with small pebbles and packed clay. Characteristic of these walls are the mudbricks underneath the lowest course of stones. The mudbricks had clearly been compacted by the stones in the wall but appear to be rectangular in shape.

The 1998 excavations at the Lohra mound focused on clarifying the layout of the boulder-constructed building extending from the west baulk 


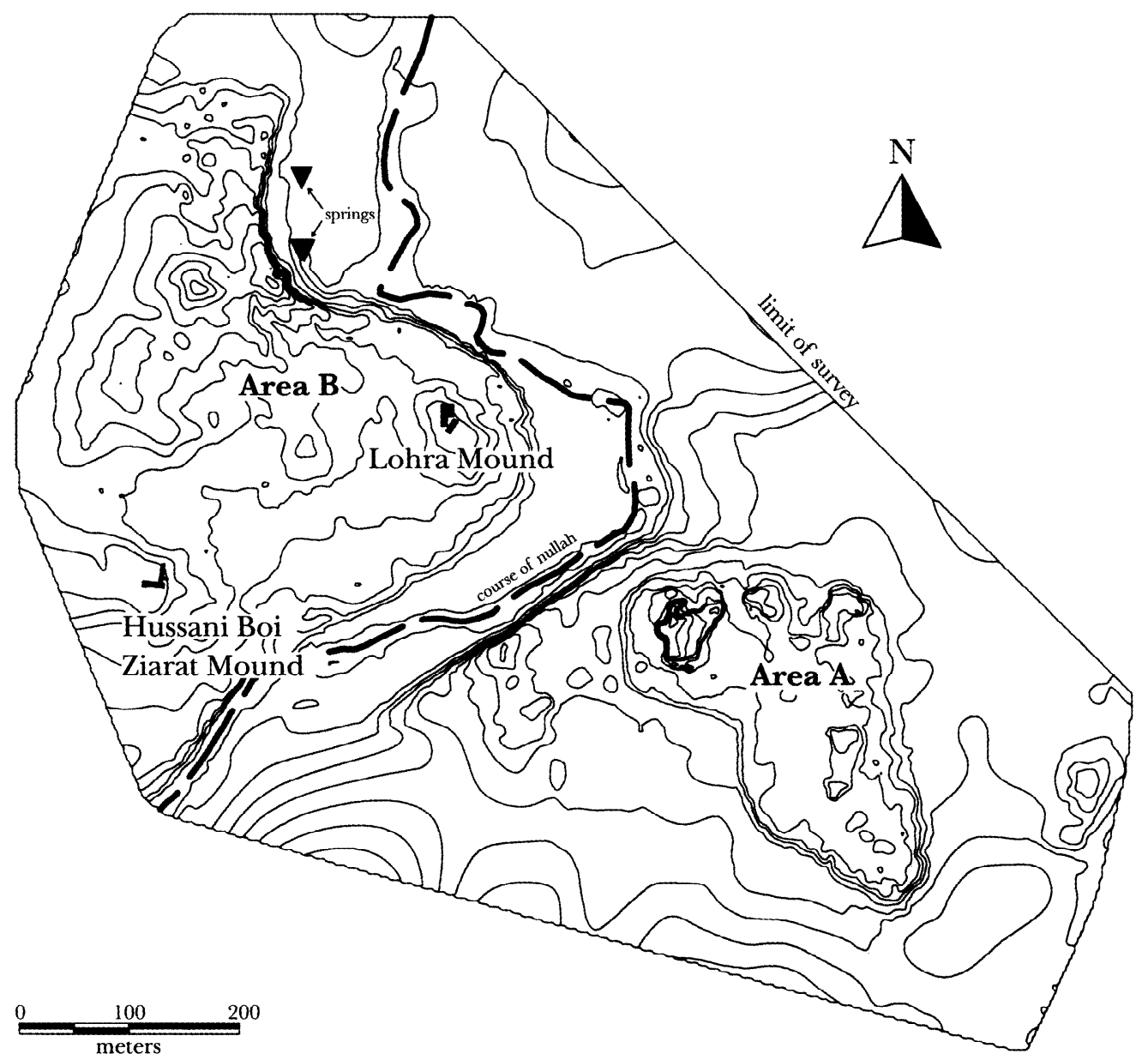

Fig. 5. Topographical plan of Akra, showing main mounds

of trench 1 (fig. 10). To achieve this, a new trench, trench 3 , was opened adjacent to trench 1 , in accordance with the visible line of the wall. Unfortunately, the recent destruction wrought upon this area of the site has meant that all the upper features of trench 3 were destroyed. However, substantial architecture in the south of trench 3 marked the continuation and return of the stone and mudbrick wall found in trench 1 . Excavations between the wall return and the western baulk of trench 3 in 2000 revealed a series of tightly compacted floor levels, many of which were plastered (fig. 11). These ran up to the wall and several courses of mudbrick underneath. Also in 2000, excavations in the north of trench 3 revealed remnants of substantial stone and mudbrick architecture that had been heavily disturbed both by its proximity to the surface and by visible modern disturbance in this area of the mound (fig. 12).

In the Lohra mound excavation two basic material culture phases could be discerned. Bannu black-on-red ware and fan-spouted vessels akin to the one discovered in the Chigkamar (CGK) sounding were found associated with the stone and mudbrick-constructed buildings, and also in the underlying deposits. Due to its stratigraphic positioning on the Lohra mound, this assemblage has been referred to as assemblage 2 . Overlying these deposits was a series of habitation surfaces and pits that contained a completely different ceramic assemblage. This group of material includes a number of vessel forms that are considered distinctively Achaemenid in date, and has been referred to collectively as assemblage 1 .

The HBZD Mound. To the southwest of the Lohra mound lies the HBZD mound. Of all the mounds at Akra, it appears to have been the least disturbed by modern activity; it has a flat upper surface, is roughly rectangular in shape, and covers an area of approximately 0.63 ha. A series of connected trenches was opened along the top of the eastern slope in a perpendicular line toward the center of 


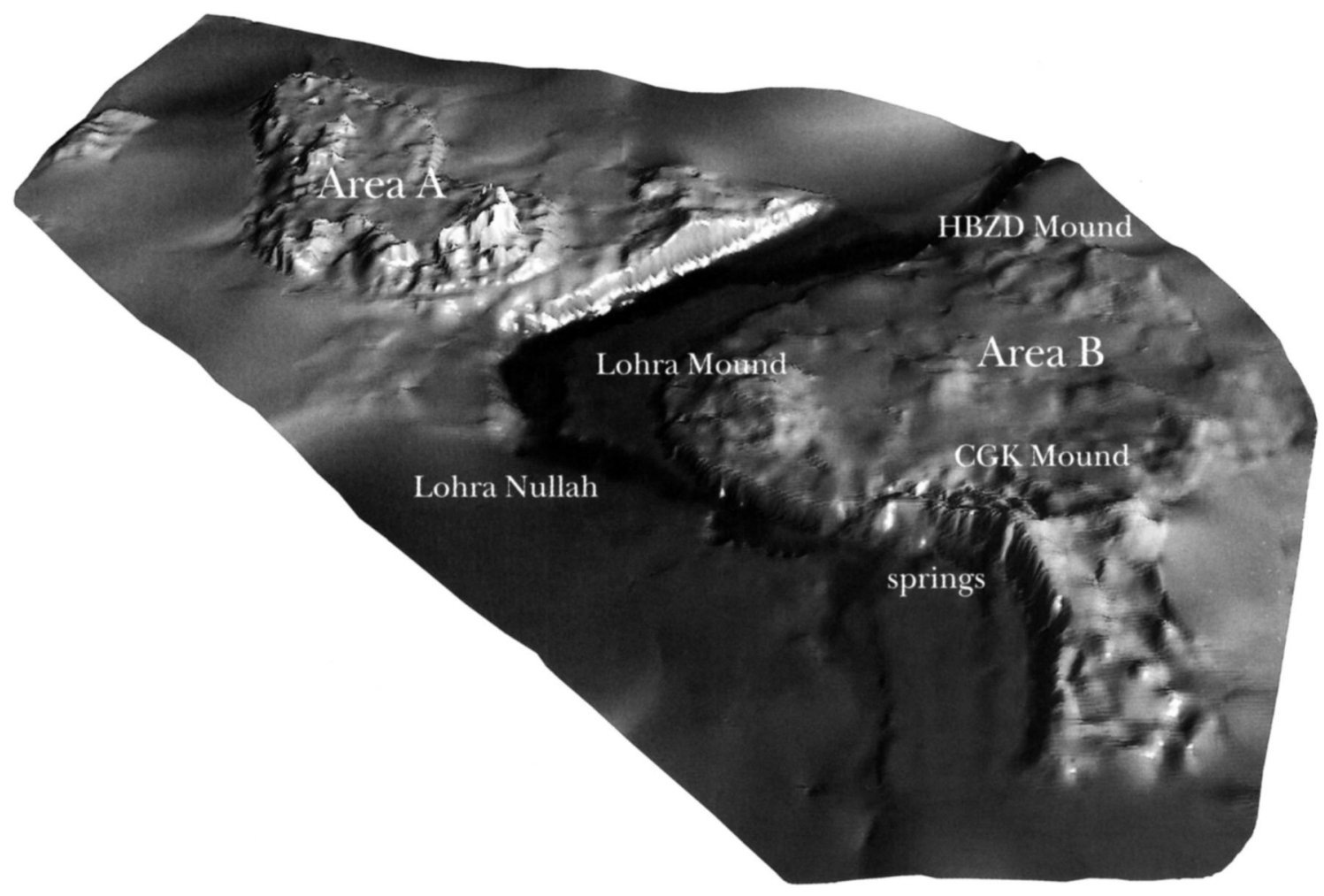

Fig. 6. Three-dimensional topographical plan of Akra looking to the south

the mound in 2000 (fig. 13) to obtain a broad horizontal exposure, and the remains of three major structural phases were revealed.

The two uppermost structural phases and an intervening pit phase displayed a homogenous assemblage of cultural material. A combination of AMS radiocarbon determinations and relative ceramic parallels has been used to suggest that these two phases date to the late first and early second millennia A.D. ${ }^{92}$ The lower of these structural phases consisted of a substantial river-stone wall and associated semicircular bastion, while the upper phase includes a rebuilding of the river-stone wall and a series of mudbrick structures.

Beneath these later Historic phases, a phase of stone and mud architecture and associated occupation deposits were revealed, with walls oriented on a different alignment (fig. 14). These walls were constructed by the same technique found on the Lohra mound, using a combination of packed mud, large river stones aligned to form a wall face, and smaller pebbles used as packing. The alignments of four walls were delineated, consisting of two dis- crete rooms, one in the eastern and one in the western areas of the excavation. In the eastern room, an occupation surface was isolated and a complete spouted vessel was found in situ, embedded in the floor. The ceramic assemblage contained most of the other elements of assemblage 2, as defined in the Lohra mound excavations, including many fragments of Bannu black-on-red ware.

\section{Ceramics}

From these three excavated areas two distinctive ceramic assemblages were isolated on the basis of stratigraphic and architectural phasing. Each contains unique forms, wares, and fabrics, which we review separately.

Assemblage 1. This assemblage was isolated to the upper levels of the Lohra mound, and is characterized by fine, well-levigated wheel-made wares. Three pastes can be defined on the basis of varying densities of mineral temper, mica, and chaff. In addition, a cooking-pot coarse ware characterized by elongated pieces of mica up to $4 \mathrm{~cm}$ in length was recovered. Open vessels, especially bowls, are of-

\footnotetext{
${ }^{92}$ Petrie (forthcoming a and $b$ ).
} 


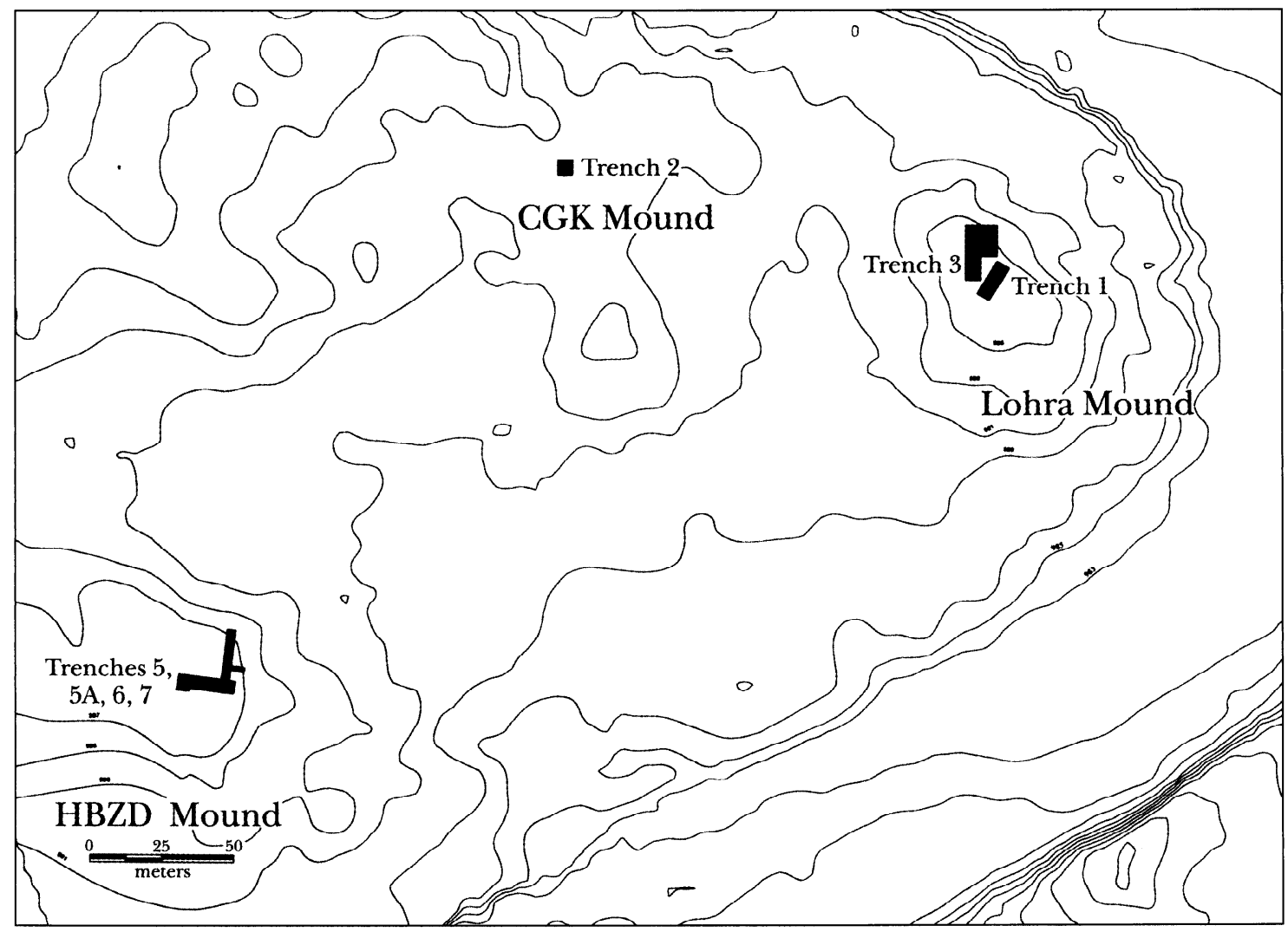

Fig. 7. Topographical plan of area B, Akra

ten decorated with a very smooth, sometimes burnished, red-orange slip.

1. Bowls with offset vertical rim (fig. 15a-c). The examples recovered at Akra often have a burnished red-brown slip. They bear some resemblance to examples from Charsadda I layer $36 \mathrm{~b}$ dated by Wheeler to the fourth-third centuries B.C. ${ }^{93}$ but convincingly redated by Dittmann to the early sixth century B.C. ${ }^{94}$ In Afghanistan, examples from Mundigak (period $\mathrm{V})^{95}$ and Kandahar (site $\left.\mathrm{H}\right)^{96}$ are "slipped or self slipped mostly plain ... generally smoothed, especially on the upper part of the exterior." 97 Further west, the form is found in southeast Iran, at Tepe Yahya, in a burnished red-brown slip and is well dated on the basis of radiocarbon and artifactual evidence from 600 B.C. onward ${ }^{98}$ It is also found in the Iron Age III period (ca. 600-300 B.C.) ${ }^{99}$ in south-

${ }^{93}$ Wheeler 1962, figs. 16.58-16.59.

${ }^{94}$ Dittmann 1984, table 5.

${ }^{95}$ E.g., Casal 1961, 2:fig. 116.605.

${ }^{96}$ McNicoll and Ball 1996, figs. 192.14, 194.54.

${ }^{97}$ Vogelsang 1985, 65-6, fig. 1; 1992, 258-9, fig. 12. eastern Arabia and the Gulf, specifically at Rumeilah, ${ }^{100}$ Tell Abraq, ${ }^{101}$ and at Qala'at al Bahrain. ${ }^{102}$

2. Banded beakers (fig. $15 \mathrm{~d}, \mathrm{e}$ ). This is an unusual form for which few parallels are found in Iron Age Pakistan. It is characterized by a slightly thickened internal lip and bands of black paint on an orange ground. Although it is more frequently made in the well-levigated wares that are common in assemblage 1, some examples are found in the coarser wares typical of assemblage 2. Some examples have decorative elements such as wavy painted lines on the exterior that resemble, to some extent, the decorative schemes found on Bannu black-onred ware, suggesting that it may represent the continuation of earlier traditions.

3. S-carinated rim bowls (fig. 16a, b). Bowls with an S-carinated rim are common in assemblage

\footnotetext{
${ }^{98}$ Magee 2004, fig. 5.35.

${ }^{99}$ Magee 1996, 240-52.

${ }^{100}$ Boucharlat and Lombard 1985, pls. 57-58.

${ }^{101}$ Magee 1995, fig. 4.9.

${ }^{102}$ Højlund and Andersen 1994, nos. 1164-1165.
} 


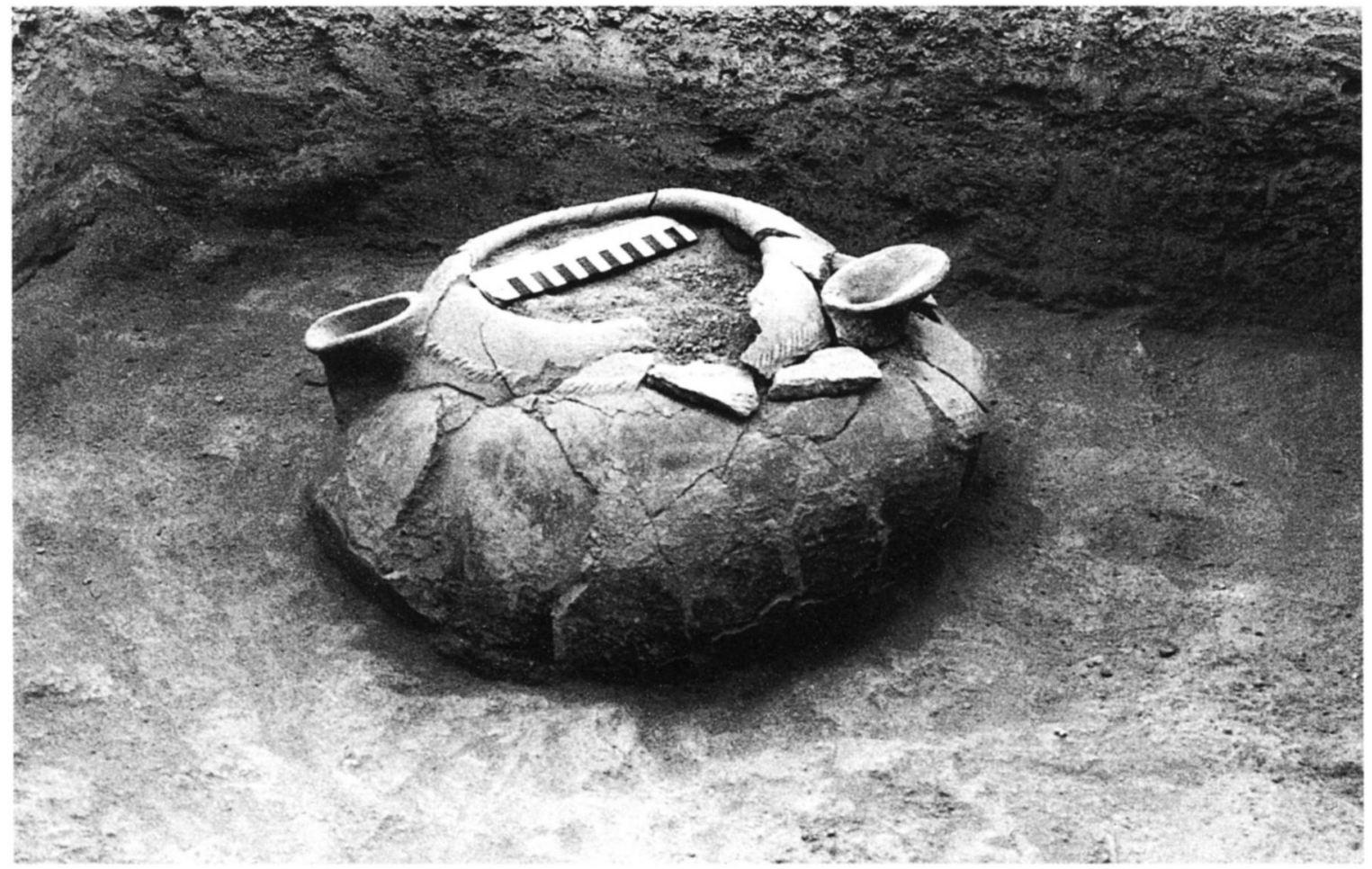

Fig. 8. View of complete fan-spouted vessel in CGK excavation

1 at Akra and are frequently decorated with a thick red, often burnished, slip. This type is known from Charsadda, where it is common in layer $27,{ }^{103}$ which Dittman dates prior to the end of the fourth century B.C. ${ }^{104}$ North of Charsadda, in the Swat Valley, examples are also known from Aligrama, ${ }^{105}$ Kalako-deray, ${ }^{106}$ Birkot-ghwandai, ${ }^{107}$ and Ghaligai. ${ }^{108}$ To the west, examples have been reported from Kandahar ${ }^{109}$ and Tepe Yahya ${ }^{110}$ and from Tal-i Zohak in the Fasa Plain from where Hansman describes examples as "red/brown, fine; surface same, burnished." 111 At all these sites a dating from the sixth to the fourth centuries B.C. has been suggested-a chronology in accord with the recovery of similar shapes at the Achaemenid capitals of Persepolis ${ }^{112}$ and Pasargadae. ${ }^{113}$

${ }^{103}$ Wheeler 1962, 40.

${ }^{104}$ Dittman 1984, table 5.

${ }^{105}$ Stacul and Tusa 1977, fig. 14 j-k.

${ }^{106}$ Stacul (1993, fig. 17o), although this example is more shallow than most.

${ }^{107}$ Stacul 1980, fig. 5.1. Similar examples are known from other sites in the Swat Valley, some of which are burnished in a very similar fashion to those from Akra. See also Stacul 1997.

${ }^{108}$ Stacul 1969, fig. 13c.

${ }^{109}$ McNicoll and Ball 1996, figs. 113.4, 80.12.

${ }^{110}$ Magee 2004, fig. 5.5.

${ }^{111}$ Hansman 1979, figs. 3.3, 4.
4. Tulip bowls (fig. 16c, d). Many examples of this shape, often smoothed or self-slipped, were discovered in assemblage 1 deposits. In Pakistan the shape is found at Charsadda layers 2228, where it is described as an "abundant but not ungraceful drinking-bowl." "114 Wheeler's date for these layers of the third to second centuries B.C. was corrected to the fourth century B.C. by Dittmann. This date accords perfectly with the examples found at Persepolis, ${ }^{115}$ Pasargadae, ${ }^{116}$ and Tol-e Spid ${ }^{117}$ in Fars, as well as surface collections from sites in the Marv Dasht. ${ }^{118}$ Good parallels are also known from the Achaemenid-period levels at Susa ${ }^{119}$ and Tal-i Ghazir on the Ram Hormuz Plain. ${ }^{120}$

Assemblage 2. This assemblage was found in each of the excavated areas and is characterized by a

\footnotetext{
${ }^{112}$ Schmidt 1954, pl. 74.1.

${ }^{113}$ Where this form was recovered from Achaemenid and post-Achaemenid deposits (Stronach 1978, fig. 107.8-10).

${ }^{114}$ Wheeler 1962, 40, fig. 10.11 .

${ }^{115}$ Schmidt 1954, pls. 67.3, 72.1, 89.8.

${ }^{116}$ Stronach 1978, pls. 106.1-13.

${ }^{117}$ Petrie et al. (forthcoming), fig. 5.93, TS 439, 495.

${ }^{118}$ Sumner 1986, fig. Ill 2.A-J.

${ }^{119}$ De Miroschedji et al. 1987, fig. 7.7.

${ }^{120}$ Carter (1994, fig. 14.3) suggests these are comparable to examples from Nippur.
} 


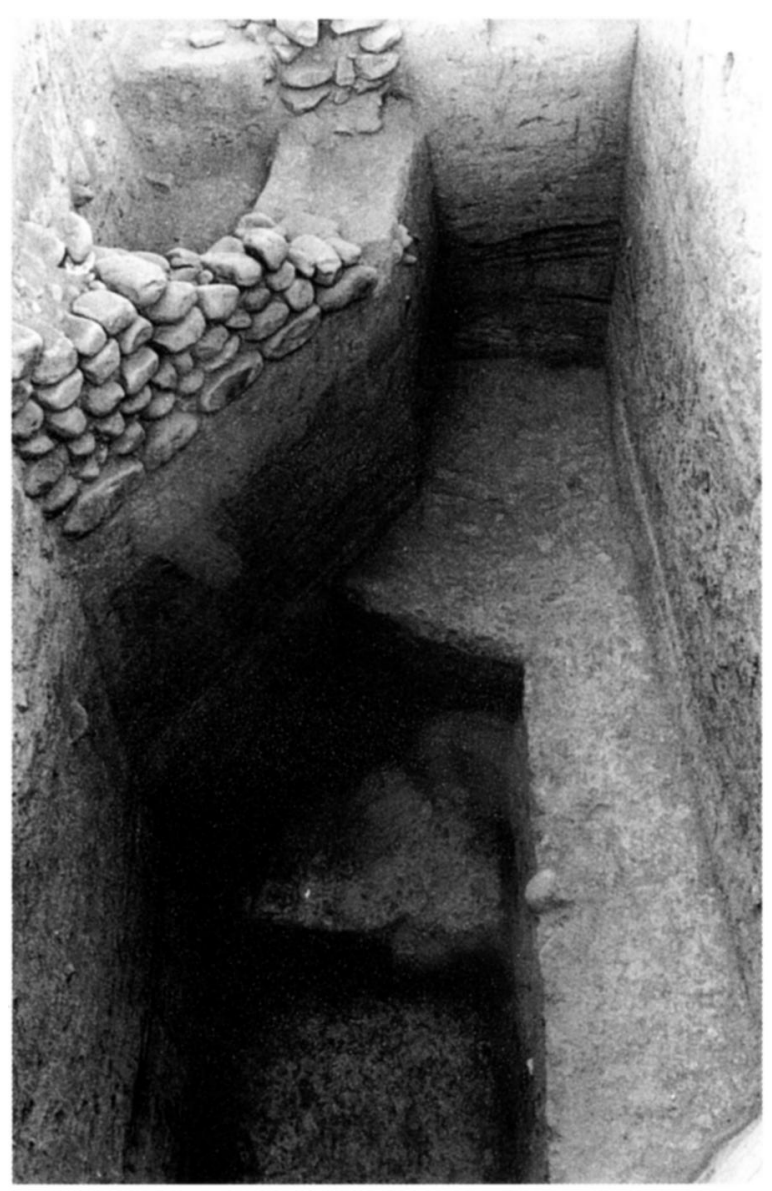

Fig. 9. View of Lohra mound toward northwest, showing stone-constructed buildings, mudbrick substructure, and deep sounding in the foreground

chaff- and mineral-tempered ware. Analysis on a macroscopic level suggests that in terms of temper it is unrelated to the wares of assemblage 1, although that does not necessarily mean that its clay comes from a different geological source. Bannu black-onred ware is the most typical feature of this assemblage. It is hand-made, often wet-smoothed, and characterized by black-on-red geometric decoration on a brown ground. Other wares in this assemblage include a brown, grog-tempered, coarse hand-made ware and a hard burnished gray ware. Only a few sherds, most of which were nondiagnostic, of the latter two wares were found. A few fragments of a hard, gray-black, highly burnished ceramic were also found, and these have tentatively been identified as northern black polished ware.

\footnotetext{
${ }^{121}$ Enault 1979, figs. 64, 70, 77.

${ }^{122}$ Casal 1961, figs. 107-115.

${ }^{123}$ Dales 1977, pls. 15.1-15.5, 28.1-28.8, 30.1-30.7.

${ }^{124}$ Summarized in English in Sarianidi 1985, 4-23.

${ }^{125}$ Masson 1959, 29-50.
}

1. Bannu black-on-red ware (figs. 17, 18). The standard form of this ware is a simple bowl with a straight wall and a slightly thickened interior rim or an incurving rim. Decoration consists of diagonal lines, bands, and wavy lies or hatched triangles. Although Iron Age painted pottery is not unknown in Pakistan, the shapes and decorative schemes found on Bannu black-on-red ware seem largely unrelated to local developments. There are general parallels between Bannu black-on-red ware and the painted forms from Pirak (period III), ${ }^{121}$ Mundigak (period V), ${ }^{122}$ and Sorkh Dagh at Nad-i-Ali (period I), ${ }^{123}$ but far more convincing parallels can be found in the ceramic corpus common in South-Central Asia in the early Iron Age. This pottery, which has been studied in depth by Sarianidi, ${ }^{124}$ has a wide distribution throughout southern Turkmenistan and Afghanistan and was found at Yaz Depe $I,{ }^{125}$ as well as Kuchuk Tepe and Chust and Dalverzin in the Ferghana Valley. ${ }^{126}$ The examples from Tillya Tepe illustrated by Sarianidi include the same decorative motifs on the same forms that occur on the Akra examples. ${ }^{127}$ The only difference is that the Akra examples are on a red or brown ground whereas the Tillya Tepe examples are on a buff or undecorated ground. Examples have also been published from the Atrek Valley in the northeast of Iran where they are described as "hand-made, of fairly course clay and painted with geometric figures (rhomboid and triangular) in brown, black, or winered on a red or, more often, a buff surface."128 This description and the forms illustrated by Venco-Ricciardi ${ }^{129}$ closely parallel examples found at Akra. In the Atrek Valley this material is dated following the Yaz Depe I/Tillya Tepe I-II chronology of 1000-650 B.C.

2. Fan-spouts (figs. 8, 19). A unique form present at Akra is the fan-spout. These are found on the shoulders of vessels and consist of both functional spouts and false spouts. Judging by the complete vessel found in area $\mathrm{B}$, trench 2 , the combination of both these forms of spouts may have been used as a handle and a spout on pouring vessels. As with Bannu black-onred ware, there are few local parallels for this form. Although Iron Age Iran, with its noted

\footnotetext{
${ }^{126}$ Zadneprovsky 1962.

${ }^{127}$ Sarianidi 1989a, pls. IV-XXVIII.

${ }^{128}$ Venco Ricciardi 1980, 58.

${ }^{129}$ Venco Ricciardi 1980, fig. d.
} 


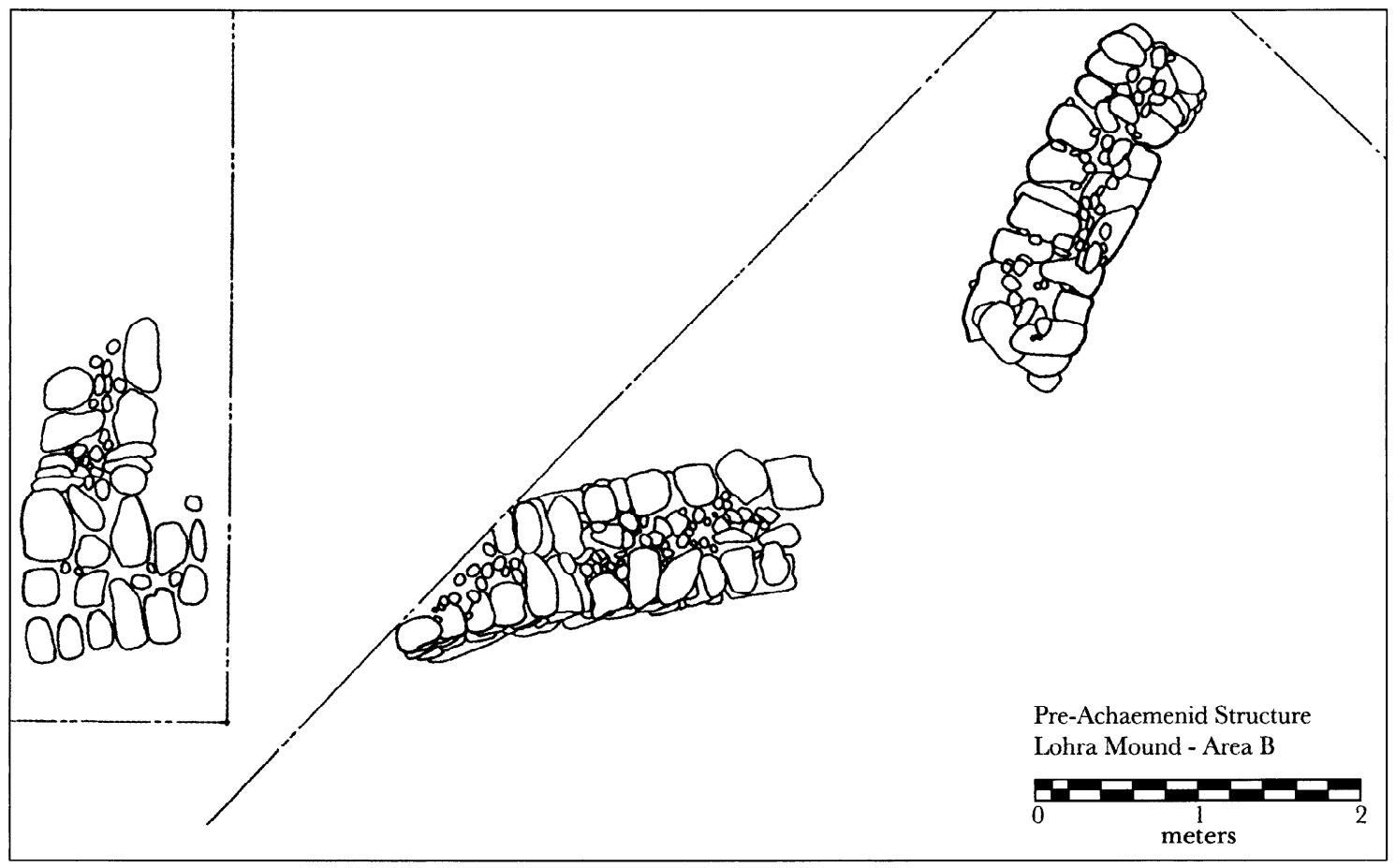

Fig. 10. Plan showing architectural remains in trenches 1 and 3, Lohra mound

tradition of spouted vessels, appears as the possible source for such a shape, a caveat is necessary. Our knowledge of Iron Age Iranian ceramics is heavily reliant on the western Iran sequences, in particular those provided by the sites of Tepe Sialk and Hasanlu. Spouted vessels are common at both these sites and are not unknown in Luristan and Fars. ${ }^{130}$ However, moving to the east and southeast they become much less common. ${ }^{131}$ Vessels with spouts were recovered from pre-Achaemenid Iron Age deposits at Pirak (period III) ${ }^{132}$ and Mundigak (period V), ${ }^{133}$ but these examples are all morphologically different from those of Akra. More accurate parallels for the Akra fan-spouts can be found in South-Central Asia alongside the painted pottery shapes discussed above. Although examples are limited, comparable spouts are known at sites such as Tillya Tepe. ${ }^{134}$

\section{Small Finds}

Forty-six pieces of iron were found in the first three seasons of excavation at Akra, the majority

\footnotetext{
${ }^{130}$ E.g., Overlaet 1997, fig. 4. This vessel, which belongs to Taimuran I phase, differs considerably from the type of spouts found in the Akra assemblage.

${ }^{131}$ E.g., they are virtually unknown in the Iron Age corpus at Tepe Yahya in southeastern Iran; see Magee 2004

${ }^{132}$ Enault 1979, figs. 66.343, 72.395, 76.416, 76.418, 79.432,
}

from area B and many from layers containing assemblage 2 ceramics. Most were nondiagnostic artifacts, while some were likely waste from iron working and smelting, including small pieces of slag. Beads of terracotta, carnelian, and other semi-precious stones were also common in assemblage 1 and 2 deposits.

\section{CHRONOLOGY}

There is a variety of evidence available that permits a broad reconstruction of when Akra was occupied. At present it appears that the site was inhabited from as early as ca. 2000 B.C. and up to as late as ca. A.D. 1200, including two distinct phases of Iron Age occupation.

There are three seals from Akra now in the collections of the British Museum that provide clues as to when the site might first have been occupied. One of these is a small, lenticular button seal with a bird of prey attacking a snake on one side and a prancing quadruped on the other, which is similar in shape to Late Harappan Jhukar seals from sites such as Chanhu-Daro in Sind. ${ }^{135}$ The other two seals

\footnotetext{
79.434 .

${ }^{133}$ Casal 1961, figs. 113, 563-563a.

${ }^{134}$ Sarianidi 1989a, pls. XL.6, XLI.7.

${ }^{135}$ Khan et al. 2000d, 54-5 n. 58 (after Lambert 1986). Illustrated in both publications.
} 


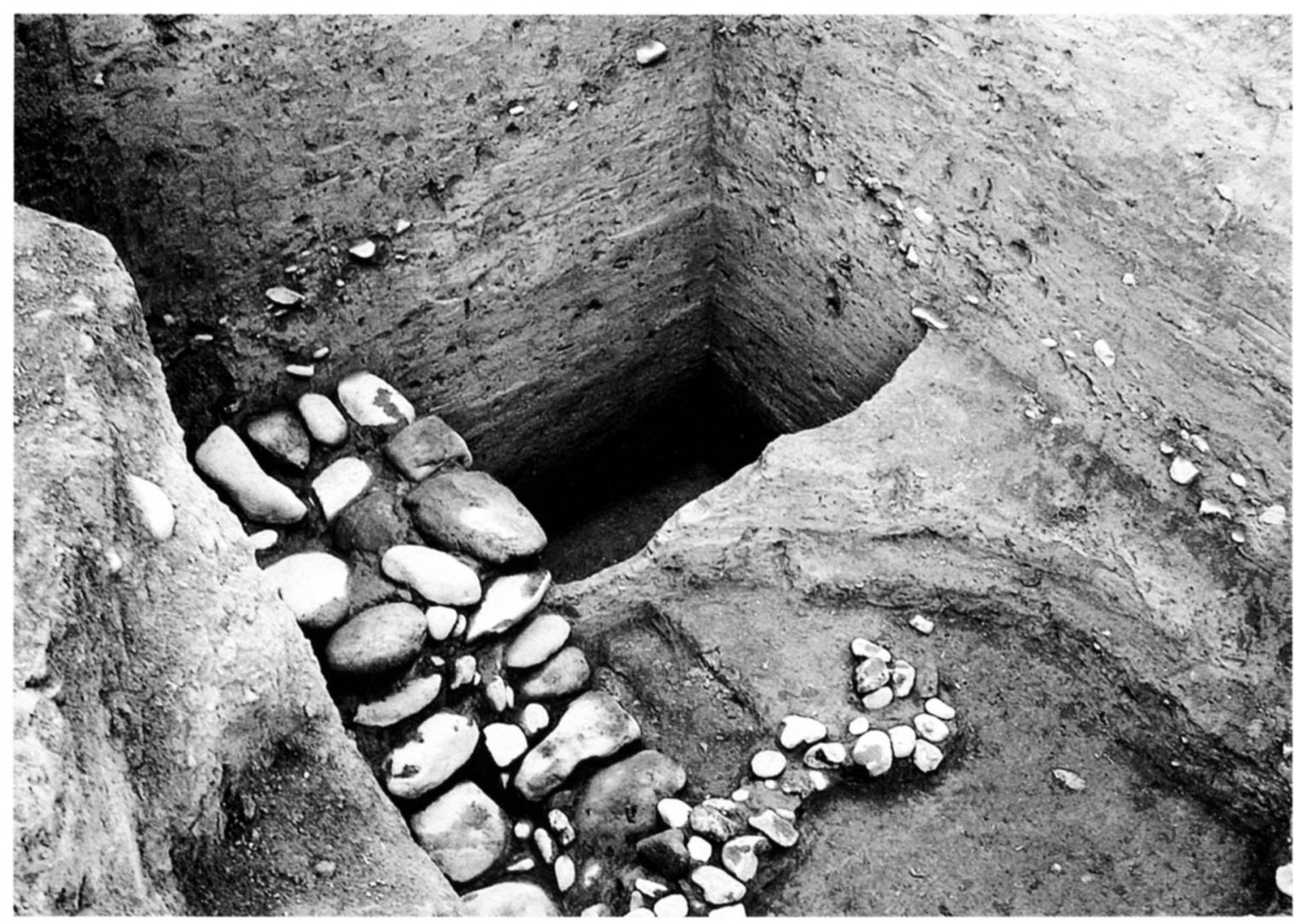

Fig. 11. Deep sounding along stone-constructed wall. Laminated floor levels are evident in the west and south baulk.

appear to be of Central Asian origin and are related to seal types found in the so-called Bactria Margiana Archaeological Complex (BMAC). One is a stamp cylinder seal of Murghab type, which has a suspension loop at one end, a repeating motif of a bird of prey attacking a snake on the vertical surface, and an identical snake shown alone on the base. ${ }^{136}$ This seal is similar in form to seals and impressions from Togolok 1 and Taip-depe 1 in Margiana, ${ }^{137}$ and is also morphologically similar to seals that have been found in graves at Sibri and Mehrgarh in Baluchistan. ${ }^{138}$ The other Central Asian seal is a steppedcross pendant made of soapstone with a fish incised on one side. ${ }^{139}$ Similar pendant seals are known from Togolok 21 and Gonur 1, ${ }^{140}$ and an example with a bird on one side was found at Harappa. ${ }^{141}$

Taken together, the three seals indicate that the earliest occupation at Akra could date to the first

\footnotetext{
${ }^{136}$ Lambert 1986; Knox 1994, 377. Illustrated in both publications.

${ }^{137}$ E.g., Hiebert 1994, fig. 9.16 (after Sarianidi 1989b, fig. 5); Masimov 1981, 211.

${ }^{138}$ Santoni 1984, 56, fig. 8.4A; Jarrige and Hassan 1989, 150.

${ }^{139}$ Khan et al. 2000d, 55, 174-6.
}

two centuries of the second millennium B.C. ${ }^{142}$ which is contemporaneous with the fragmentation of the Mature Harappan civilization in the Indus Valley, and the expansion of the BMAC from Central Asia. BMAC material is widespread in the Central Asian oases, but it is also known from sites in southwestern, northern, and southeastern Iran, northern Afghanistan, and Baluchistan. ${ }^{143}$ In seeking to explain the appearance of clusters of BMAC material at sites in Iran and Pakistan in a context of completely different local material cultures, Hiebert has suggested this is evidence of the movement of Central Asian people who were searching for resources through conquest or trade. ${ }^{144}$ Thus far, there has been no stratified occupation containing contemporary material isolated at Akra, so there is no context for establishing the nature of the relationship between the BMAC and the Bannu

\footnotetext{
${ }^{140}$ Sarianidi 1981, 232-3, figs. 7, 8; see also Hiebert 1994, fig. 9.14-9.16.

${ }^{141}$ Vats 1940, 319, pls. 91, 255.

${ }^{142}$ Khan et al. $2000 \mathrm{~d}, 55$.

${ }^{143}$ Summarized in Hiebert 1994, 163-4, 178.

${ }^{144}$ Hiebert 1994, 163-4, 177-8, fig. 10.8.
} 


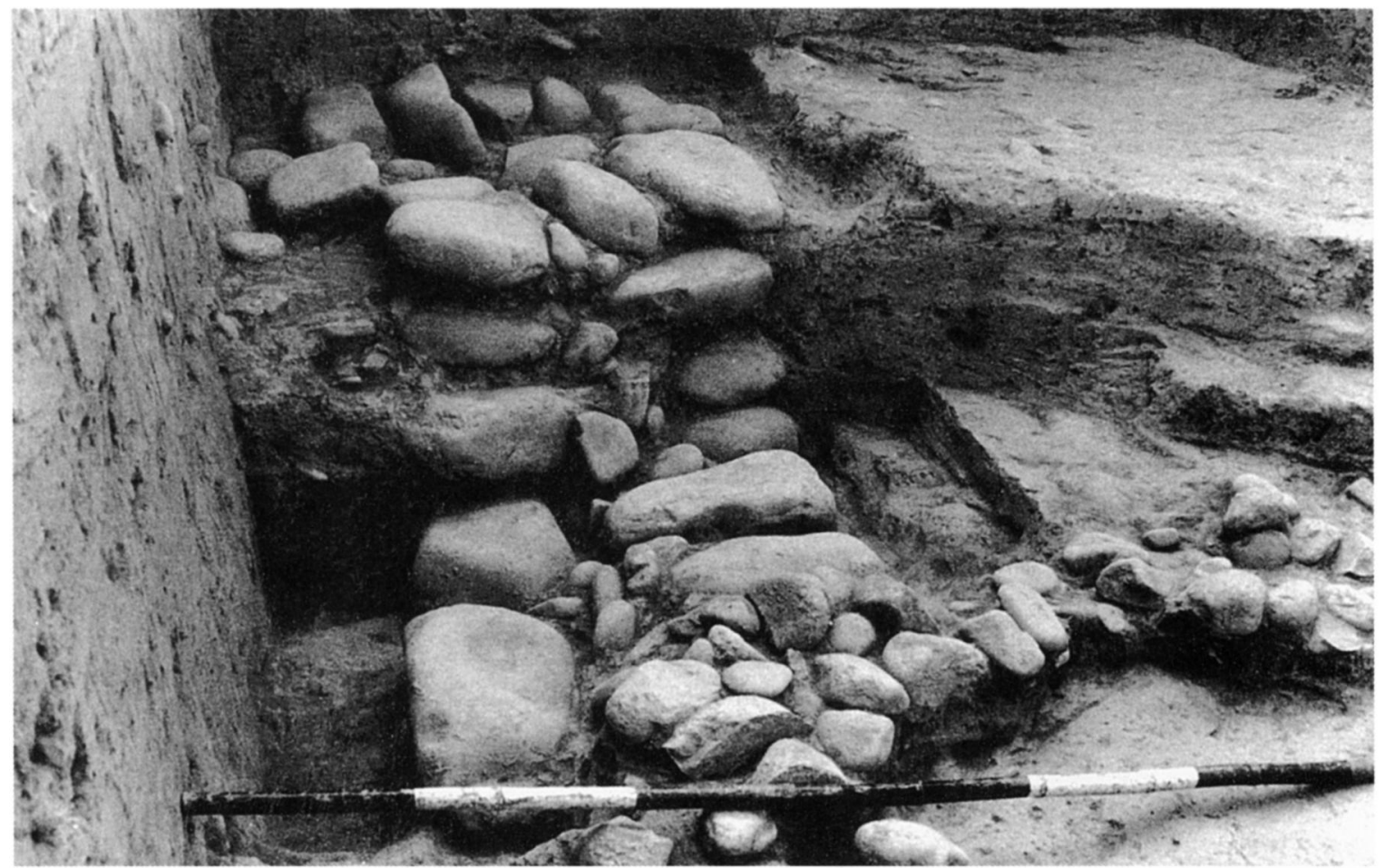

Fig. 12. View of trench 3, Lohra mound, showing destruction of wall

region. However, at the least, the discovery of the early second millennium B.C. BMAC seals at Akra implies that there was interaction between the Bannu region and Central Asia at this time.

On the basis of the stratigraphic and radiocarbon evidence, the earliest in situ levels at Akra are those associated with Bannu black-on-red ware and fan spouts (assemblage 2). In the three excavations conducted in area B, Bannu black-on-red ware was very common, and it remains the most common surface material across this part of the site. As noted above, preliminary information on the chronology of the Bannu black-on-red ware horizon was provided by two radiocarbon dates from Ter Kala Dheri. ${ }^{145}$ The radiocarbon ages and the probability distributions for each are shown in table 1 . Of the two samples, OxA 6239 was recovered from an upper floor and BM 2979 from a lower floor, although it should be pointed out that these surfaces were not separated by a significant depth of deposit. It is important to note that OxA 6239 intercepts the calibration curve at a plateau, which results in a wide probability range for any samples with calendar ages between ca. 750 and 400 B.C. Irrespective

\footnotetext{
${ }^{145}$ These and all the other dates presented in this paper have been calibrated using OxCal 3.8, which utilizes the
}

of this proviso, the two dates from Ter Kala Dheri suggest that the Bannu black-on-red ware horizon at that site dates from the early to mid first millennium B.C. To further investigate this, an intensive program of C14 dating was undertaken at Akra.

From Akra CGK mound, one sample was obtained on the floor on which rested the large spouted vessel (table 2). The probability distribution for this sample falls predominantly before the large plateau on the calibration curve, which starts at ca. 750 B.C., indicating that there is a high likelihood that the floor was in use after 930 B.C.

The excavations on the Lohra mound have been the most extensive, and it is from here that the largest number of radiometric assays was obtained (table 3). From trench 1, two samples were analyzed-one from deposits associated with the stone-constructed building that contains assemblage 2 material, and one from the deposits just below this structure. $\mathrm{Al}-$ though Beta 129791 comes from a deposit immediately underlying the structure, both it and NZA 10990 are statistically the same. ${ }^{146}$ It is, therefore, possible that NZA 10990 has been incorporated into the habitation deposits from an immediately prior

\footnotetext{
IntCal98 calibration curve.
}

${ }^{146} \mathrm{~T}=1.87 \times 2(0.5)=3.84$. 


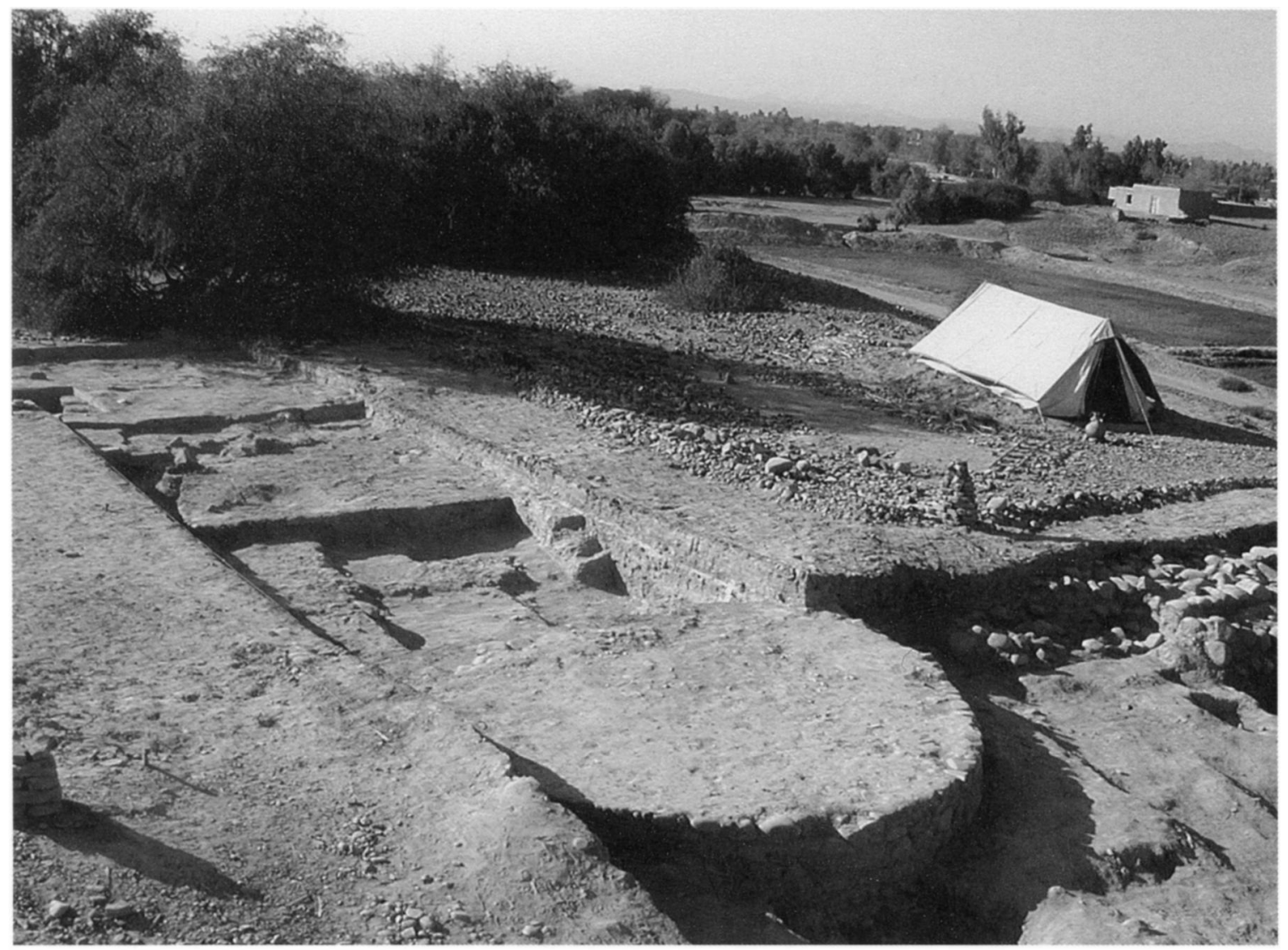

Fig. 13. View of HBZD mound after 2000 season of excavation

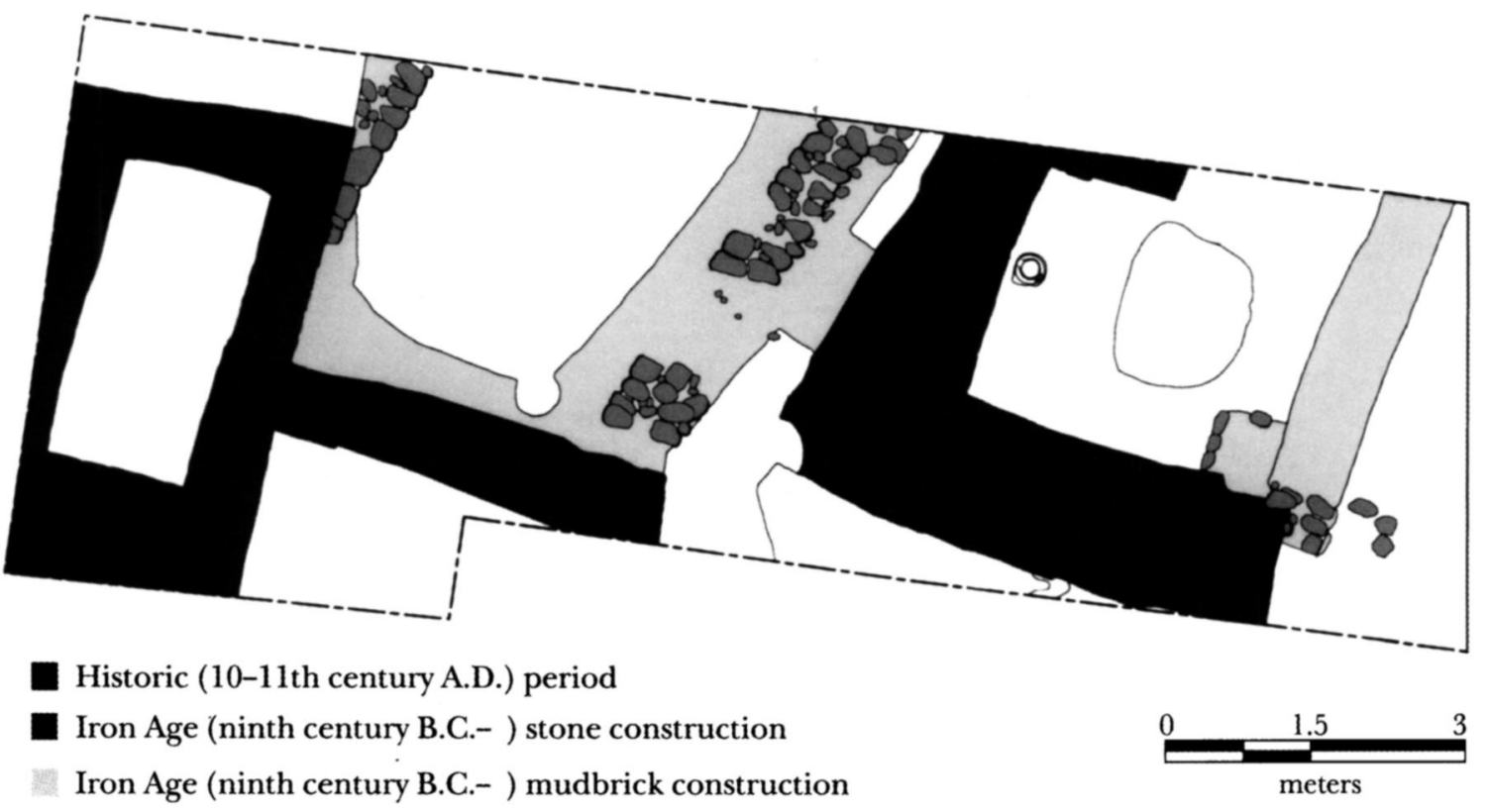

Fig. 14. Plan of Iron Age and Historic architecture in HBZD mound 
event such as a clearing fire for the construction of the building. The other samples from the Lohra mound were obtained in the deep sounding excavated into the hardened floor levels between the stone and mudbrick wall return and the western baulk in trench 3 . On the basis of stratigraphy the earliest floor level is Locus 3112 for which a date was obtained suggesting a terminus post quem of ca. 900 B.C. The sequence of floor levels above this provided further chronometric assays that indicate continued occupation into the ninth century B.C. The latest sampled floor (Locus 3100) has a terminus post quem of ca. 800 B.C., suggesting that the building still stood into the eighth century B.C.

Two radiocarbon determinations were obtained from the HBZD mound, one from the fill deposits associated with the river-stone and mud walls to the west of the excavated area (OZF 094) and the other from a collapse deposit overlying the occupation surface with the intact fan-spouted storage vessel to the east (OZF 093) (table 4). Interpretations of these two dates are slightly hampered by the unusually high error in OZF 093. Nonetheless, the upper limit of this sample suggests that the Iron Age occupation of this part of the site has a terminus post quem of ca. 900 B.C. The probability range for OZF 094 suggests that the occupation of the two mudbrick and stone-constructed buildings continued into the eighth century B.C.

On the basis of these numerous radiocarbon samples, two important conclusions can be made regarding the chronology of Iron Age occupation at Akra. The first concerns the relationship between Akra and the Ter Kala Dheri mound. The earliest date from Ter Kala Dheri (BM 2979: 1000-760 B.C.) and the earliest date from Akra (OZF 092: 920-800 B.C.) are statistically the same and suggest that the settlement of Ter Kala Dheri was part of a contemporary hinterland to the main occupation at Akra. Second, and most important, dates obtained from the three excavation areas in area $B$ are remarkably similar in their radiocarbon and calendar ranges. They all suggest a terminus post quem of ca. 900 B.C. for the occupation of area B. The subsequent dates from the HBZD mound and the Lohra mound suggest that the occupation continued into the eighth century B.C. Although one must move cautiously from this observation to conclusions concerning the size of settlement during this period, the chronological evidence for the contemporaneous nature of occupation in these areas permits a mini-

${ }^{147}$ Khan 1986, 184. mum occupation area to be calculated. Even if we were to take the three areas as the very boundaries of occupation in this period, our observations concerning the abundance of Bannu black-on-red and later wares on the surface suggest that from ca. 900 B.C. onward the settlement covered most of what we have defined as area $\mathrm{B}$, or approximately 20 ha of settlement. Only further excavations could provide this most cautious estimate with a more solid basis.

No radiocarbon assays were obtained from the deposits containing assemblage 1 ceramics. However, the parallels presented above are unanimous in suggesting that this assemblage dates between ca. 600 and 300 B.C., or the period that coincides with the Achaemenid annexation of northwestern South Asia. Determining the extent of occupation at Akra during this period is made difficult by the lack of preservation in area B and the lack of systematic excavation in area A. Nevertheless, there is evidence that suggests that Akra continued to be occupied extensively in the final centuries B.C. and the first centuries A.D. The most telling evidence for the exact chronology of the settlement at this time is available from the many coins that have been found on the surface and those that have been excavated since 1996. While their definitive publication is not yet complete, it is sufficient to state that collections of coins from the site currently held in the British Museum, Ashmolean Museum, and Peshawar Museum include those of the IndoGreek kings Apollodotus, Hermaeus, Demetrius, Strato, Atimachus, Menander, the Parthian king Gondophases, the Skythian kings Maues and Azes, the Kushan king Kidara Kushan, as well as those of Hepthalite rulers, Hindu Shahi rulers, and a lone silver coin of Mahmud of Ghazni, dating to the 11th century A.D. ${ }^{147}$ Furthermore, excavations on the HBZD mound have indicated that the settlement continued to be occupied into the 12th century A.D. ${ }^{148}$ It would seem unlikely, therefore, given the evidence for the Iron Age and Historic period (ca. 250 B.C. to 12 th century A.D.) occupation throughout the site, that the settlement did not also witness considerable occupation in the period between 600 and 300 B.C.

\section{DISCUSSION: THE SIGNIFICANCE OF AKRA}

Akra is clearly one of the few sites in northwestern Pakistan that may contain a material culture sequence from at least ca. 1000 B.C. to ca. A.D. 1000. The majority of our evidence so far relates to the

\footnotetext{
${ }^{148}$ Petrie (forthcoming a and b).
} 


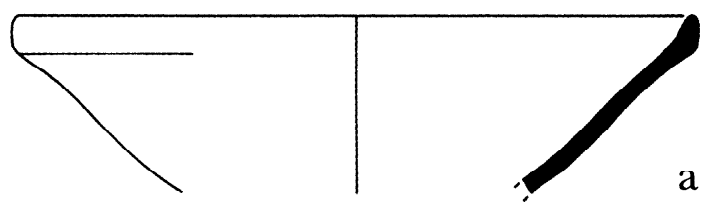

a

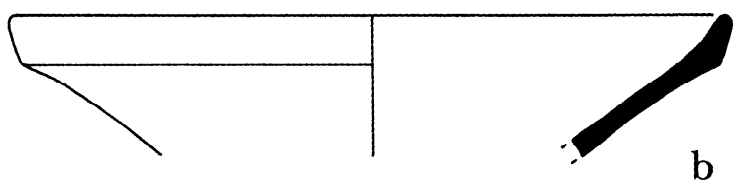

b

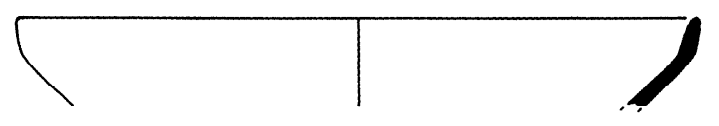

C

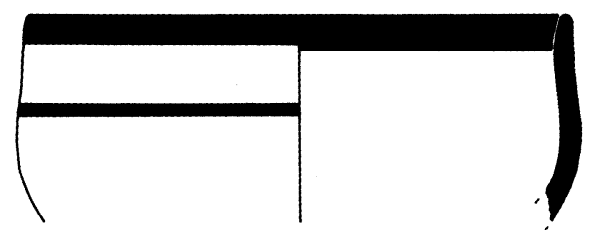

d

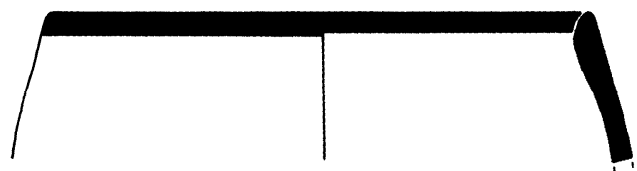

e

Fig. 15. Assemblage 1 ceramics. Lohra mound. Bowls with offset vertical rims and banded beakers. Scale in $\mathrm{cm}$.

first millennium B.C., and it is to that period that we will limit the following discussion. It is clear that the remains of this period hold the potential to provide information on one of the outstanding and unresolved questions in South Asian archaeology: the archaeology of the Achaemenid annexation of this region in the sixth century B.C.

\section{Akra-Capital of Thatagus?}

While Thatagus is mentioned in Achaemenid royal inscriptions of Darius, Xerxes, and Artaxerxes II, ${ }^{149}$ and its inhabitants have been identified on royal reliefs at Persepolis and Naqsh-i Rustam, ${ }^{150}$ there is

\footnotetext{
${ }^{149}$ Kent 1953, 187; Vallat 1993, 240.

${ }^{150}$ Schmidt 1970, 85, 107, pls. 25, 76-79; Bivar 1988, 20810; Hachmann 1997, 195-224, and references.

${ }^{151}$ Vogelsang 1990, 100; 1992, 110-4, 129.

${ }^{152}$ Vogelsang 1992, 129.
}
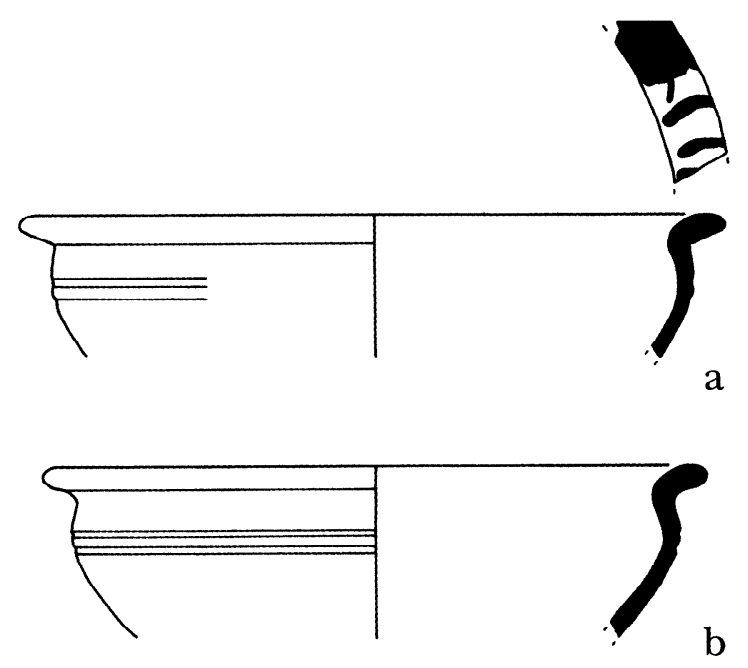

b

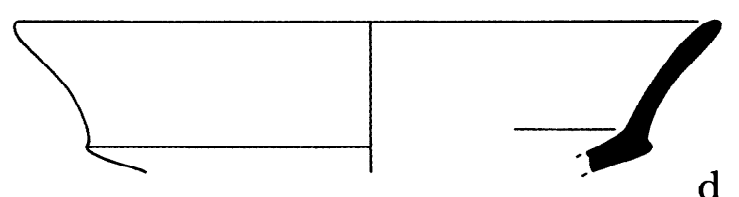

d

Fig. 16. Assemblage 1 ceramics. Lohra mound. Bowls with Scarinated rims and tulip bowls. Scale in $\mathrm{cm}$.

no real consensus on the issue of where it is located. As mentioned above, there are indications that Thatagus was administratively associated with Arachosia, ${ }^{151}$ but proposals on its specific geographical location have ranged from the suggestion that it lay in the area to the south or southeast of Kabul, ${ }^{152}$ to the more precise suggestion of the region around the Gomal River in North West Frontier Province, ${ }^{153}$ or the area of Multan in the Punjab. ${ }^{154}$ However, thus far, no convincing archaeological evidence has been found that supports any of these suggestions.

In 1982 Fleming suggested that the capital of Thatagus was located in the Bannu Basin and that

\footnotetext{
${ }^{153}$ Dani 1971, 1; Bivar 1988, 200.

${ }^{154}$ Vogelsang 1985, 80-1; 1990, 100. Although Vogelsang has now modified this $(1992,129)$, he does maintain that there were specific connections with the lower Punjab and Arachosia $(1992,227-8)$.
} 
Akra was the most likely candidate, ${ }^{155}$ basing his argument on the testimony of the Behistun inscription and a reconstruction of the campaigns and battles between the lieutenant of the Persian rebel named Vayazadata and the loyal satrap of Arachosia, Vivana. ${ }^{156}$ Bivar has rightly pointed out that Fleming's suggestion was based on geographical and historical data alone and that the terrain around Bannu had been insufficiently explored for this interpretation to carry weight, ${ }^{157}$ while Vogelsang objected to Fleming's identification on the basis that it would mean that Thatagus was too close to the satrapy of Gandhara, ${ }^{158}$ which is centered in the Peshawar Valley and might also include the upper reaches of the Kabul River Valley. While there is little distance between Bannu and Peshawar as the crow flies (ca. $150 \mathrm{~km}$ ), the two regions are separated by a section of the Salt range that has acted as a cultural barrier since the Neolithic period. There is also some additional evidence from the classical sources that indicates the importance of a small district to the west of the Indus, which might be the Bannu Basin.

In describing Alexander's march toward Drangiana, Arrian notes that Barsentes, satrap of the Drangians and Arachosians, flees to "the Indians on this side of the Indus." ${ }^{159}$ Following the conquest of Arachosia and while on his way north to Parapomisadae (Kabul/Begram), Alexander is said to have approached "the Indians who lived nearest to the Arachosians." ${ }^{160}$ It is not possible to establish whether "the Indians on this side of the Indus" and "the Indians who lived nearest to the Arachosians" are actually the same group inhabiting the same region, but geographically they both must lie somewhere to the east and north of Kandahar and to the south and southeast of Kabul. ${ }^{161}$ The terms used by Arrian also bring to mind a relationship between Harauvatish and Thatagus that is evidenced in the Achaemenid royal inscriptions. Furthermore, according to Quintus Curtius, while Alexander was later staying in Taxila, Barsentes was handed over in chains, along with Samaxus, who was "the king of a small district of India who had allied himself with

\footnotetext{
${ }^{155}$ Fleming 1982, 102-22.

${ }^{156}$ In DB, Darius claims that Vivana was both the satrap of Arachosia and a Persian (DB, sec. 45, 3.55-56; Kent 1953, 1267). Vogelsang $(1998,218)$ has argued that this attribution might well be a post-facto simplification, and that Vivana and Dadarshish, the other satrap named in DB, might have been Bactrians who only subsequently sided with Darius.

${ }^{157}$ Bivar 1988, 200.

${ }^{158}$ Vogelsang 1985, 80-1; 1992, 129.

${ }^{159}$ Arrian 3.25.8 (Brunt 2004); Vogelsang 1992, 227; also
}

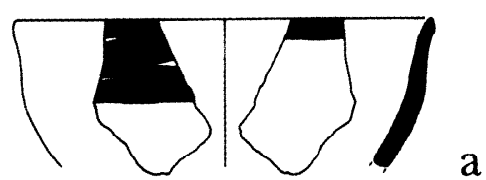

a

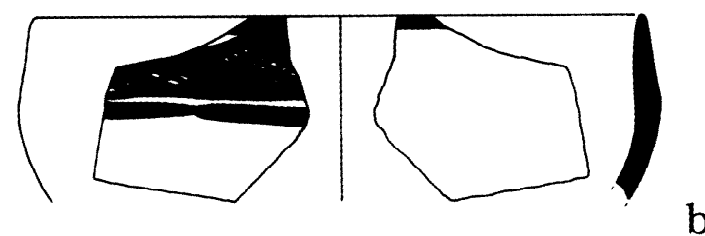

b
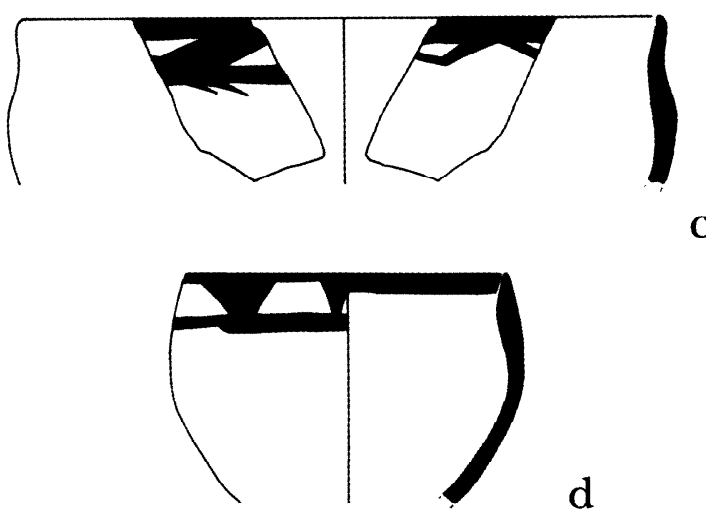

C

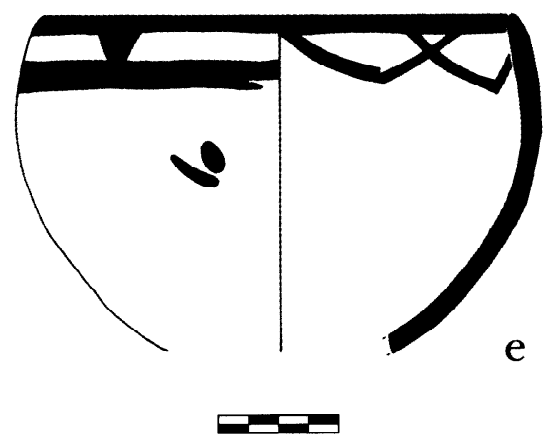

Fig. 17. Assemblage 2 ceramics. Lohra, CGK, and HBZD mounds. Bannu black-on-red ware. Scale in $\mathrm{cm}$.

Barsentes." 162 Although it is not possible to identify the precise location of this "small" territory, it presumably was south of both the Peshawar region and the areas near the Indus that were traversed by $\mathrm{Al}$ -

Quintus Curtius 6.6.36 (Rolfe 1976); Briant 2002, 757.

${ }^{160}$ Arrian 3.28.1 (Brunt 2004); Vogelsang 1992, 227. Could Alexander have been pursuing Barsentes?

${ }^{161}$ Although Briant (2002) does not discuss this issue, he includes a map that shows the area visited by Alexander at this time to be the Quetta/Pishin area of Baluchistan (Briant 2002, 755, map 7).

${ }^{162}$ Quintus Curtius 8.13.3-5 (Rolfe 1976); Vogelsang 1992, 227; Bosworth 1995, 260; Briant 2002, 757. 


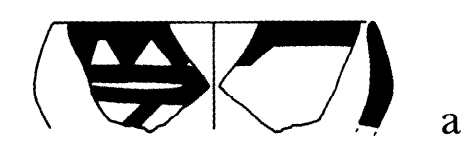

a

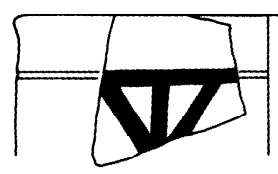

b

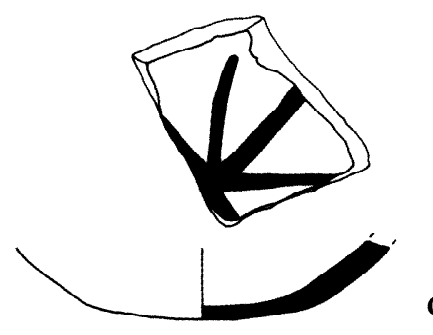

C

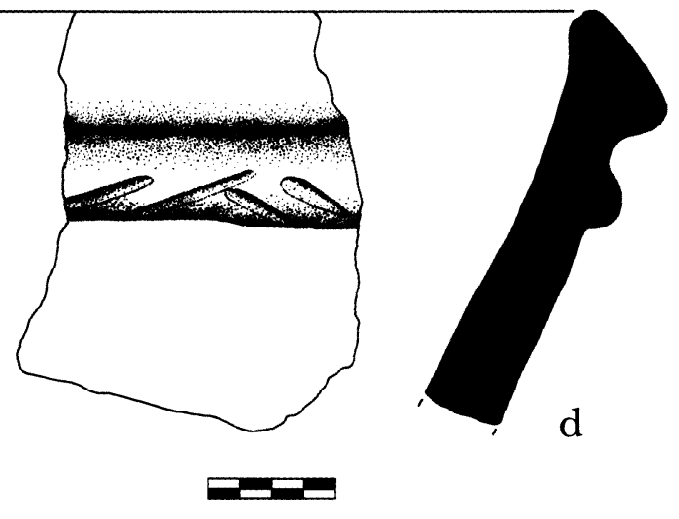

Fig. 18. Assemblage 2 ceramics. Lohra, CGK, and HBZD mounds. Bannu black-on-red ware. Scale in $\mathrm{cm}$.

exander and his men on their route to Taxila, as these regions had different named rulers. ${ }^{163}$ It is tempting to presume that in escaping to the land of the Indians on this side of the Indus, Barsentes fled to Thatagus and its local ruler (in this case Samaxus), who had previously been his subordinate.

Now that work has begun at Akra, it is clear that there is a significant Achaemenid-period component, and our topographic survey has shown that it is the largest site and the only one in the Bannu region that definitely contains such occupation. If we accept that the Achaemenid-period occupation was contiguous to that of the Iron Age throughout area $B$, then the size of Akra is on par with provincial capitals like Kandahar and Charsadda and the case for the identification of Akra as capital of Thatagus is strengthened. ${ }^{164}$ The location of the

\footnotetext{
${ }^{163}$ These regions were previously ruled by Astis (Peucelaotis) and Cophaeus and Assagetes (regions close to the Indus); Arrian 4.22.8, 4.28.49 (Brunt 2004).
}

Bannu Basin also fits the geographical requirement of being both close to Arachosia and on the west of the Indus, indicating that it is entirely plausible that in fleeing from Alexander, Barsentes might have gone to the Bannu basin, where his subordinate Samaxus was king. However, until further fieldwork is conducted, this suggestion must remain within the realm of conjecture. In any case, the identification of pre-Achaemenid deposits at Akra has perhaps greater implications for our understanding of the effects of the Achaemenid empire in the east than the historical identification of the settlement, and it is to this issue that we will now turn.

\section{Akra and the Benefits of Empire}

In the quotation from Wheeler cited in the introduction (see page 7 ), much emphasis was placed on the advent of empire to explain the emergence of urban entities in northern South Asia. The excavations at Akra have shown that this was not the case. By sometime in the early first millennium B.C., Akra was already a large, and possibly urban, center. The correlation of radiocarbon dates from within the settlement leaves little doubt that at least area B, or
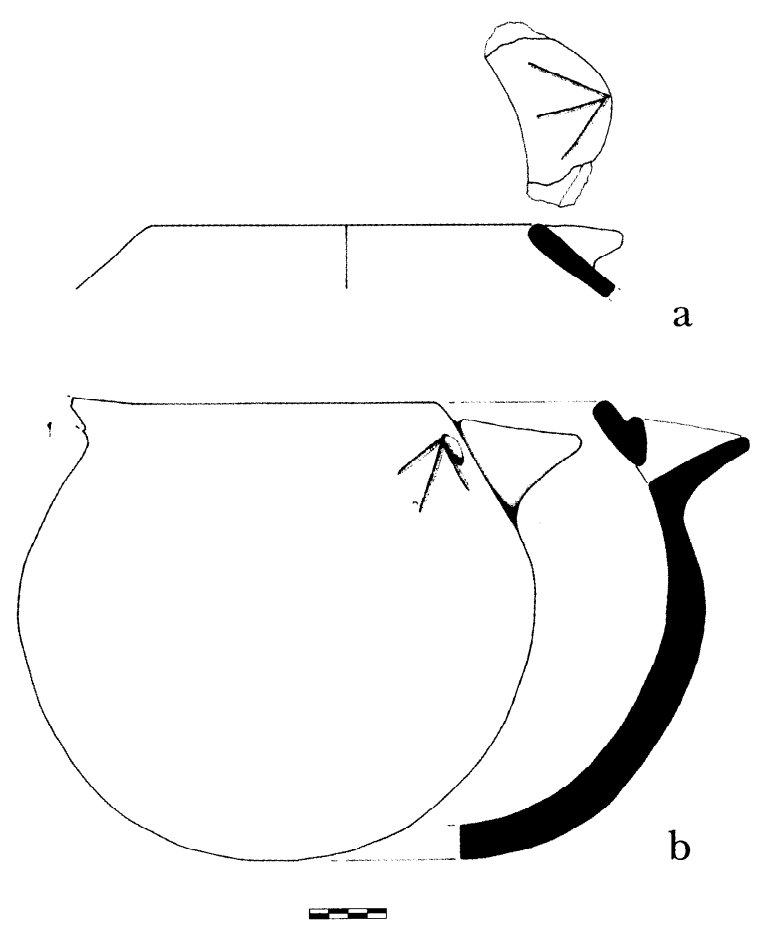

Fig. 19. Assemblage 2 ceramics. HBZD mound. Fan-spouted vessel. Compare similar example from CGK mound (fig. 8). Scale in $\mathrm{cm}$.

\footnotetext{
${ }^{164}$ Coningham $(1995,58)$ records the following site sizes: Hastinpaura (ca. 1100-800 B.C.) 6.5 ha; Kausambi (ca. 1000600 B.C.) 10 ha; Pirak (ca. $1600-800$ B.C.) 9 ha; Anuradhupura
} 
Table 1. Radiocarbon Dates for Bannu Black-on-Red Ware from Ter Kala Dheri

\begin{tabular}{lcccc}
\hline Sample & Provenience & ${ }^{14} \mathrm{C}$ Age & $\begin{array}{c}\text { Probability } \\
\text { Distribution } 95.4 \%\end{array}$ & Relative $\%$ \\
\hline OxA 6239 & TKD95/S2 upper floor & $2470 \pm 60$ b.p. & $780-400$ B.C. & $95.4 \%$ \\
BM 2979 & TKD95/S2 lower floor & $2680 \pm 60$ b.p. & $1000-760$ B.C. & $95.4 \%$ \\
\hline
\end{tabular}

Table 2. Radiocarbon Dates for Bannu Black-on-Red Ware from CGK Mound, Akra

\begin{tabular}{lcccc}
\hline Sample & Provenience & & $\begin{array}{c}\text { Probability } \\
\text { Distribution } 95.4 \%\end{array}$ & Relative \% \\
\hline \multirow{2}{*}{ NZA 19089} & ${ }^{14} \mathrm{C}$ Age & & & \\
& layer 3 & $2463 \pm 60$ b.p. & $930-750$ B.C. & $85.8 \%$ \\
& $(44$ cm below surface) & & $690-660$ B.C. & $2.6 \%$ \\
& & $650-540$ B.C. & $7.0 \%$ \\
\hline
\end{tabular}

about 20 ha of the present site, was already occupied from 900 B.C. onward. This would make the Iron Age settlement of Akra one of the largest within this time frame in South Asia. The dates from Ter Kala Dheri suggest that there was also an important hinterland for which Akra was the central place. In future research it will be critical to investigate the cause of this settlement intensification, in particular its agriculture and irrigation base. However, there is little doubt that the settlement system of the early first millennium B.C. in the Bannu Basin is markedly different from that which existed before. The position of Akra alongside a seasonal waterway that provides both water and communication routes is analogous with the emerging settlement system found in Bactria and Margiana at this time. ${ }^{165}$ It is notable that in assessing the impact of Achaemenid rule in Central Asia, Francfort and Briant both have stressed that the Achaemenids were not responsible for introducing irrigation, urban development, and "civilization" to Central Asia, but rather all these things existed in the earlier Iron Age. ${ }^{166}$ The possibility that climatic factors may be responsible for the emergence of such systems has been suggested for other parts of the Indo-Iranian borderlands, ${ }^{167}$ but only continuing fieldwork at Akra will illuminate what local environmental or technological factors account for the sudden emergence

(ca. 600-450 B.C.) 18 ha; Bala Hissar (Charsadda) 13 ha; Taxila 13 ha; Inamgaon (ca. 1600-700 B.C.) 5 ha; Daimabad 30 ha.

${ }^{165}$ Biscione 1981, 203-13; Francfort 1988, 169, 181-93; Briant 2002, 752-3. As noted, the similarity between the Central Asian environmental conditions and those in the northwest Bannu Basin were initially commented on by Stein $(1905,6)$. of such large settlements with all that that entails in terms of political and economic organization.

In Wheeler's summary of the effects of imperial control, he surmised that interregional trade was a benefit of Achaemenid annexation. According to him, this was attributed to the increased security brought about by the emergence of cities. Indeed, the many parallels that can be drawn between assemblage 1 at Akra and sites within South Asia (e.g., Charsadda), in eastern areas of the empire (e.g., Dahan-i Ghulaman), and in the Iranian heartland itself (e.g., Persepolis, Pasargadae, Tol-e Spid) would seem to indicate that this is a period of unprecedented interaction and trade over long distances. However, the evidence from Akra suggests that large, possibly urban, entities with local economies and extensive trade and exchange networks were already in existence in this region from ca. 900 B.C. The parallels that can be drawn between Bannu black-on red ware and the Yaz Depe I culture suggest that interaction and long-distance, overland trade were already occurring. In fact, the BMAC seals found at Akra emphasize that the evolving cultures of Central Asia had a protracted interest in the frontier regions along the western edge of South Asia from at least the second millennium B.C.

While resource extraction and long-distance trade using established routes may indeed have

\footnotetext{
${ }^{166}$ Francfort (1988, esp. 169), where he aptly notes, "The Achaemenids did not found Bactra, they did not invent irrigation, they did not create the civilization of Central Asia, but they coveted its riches when their time came" (Briant 2002, 752-3).

${ }^{167}$ Magee 2004, 76-9.
} 
Table 3. Radiocarbon Dates for Bannu Black-on-Red Ware from Lohra Mound, Akra

\begin{tabular}{|c|c|c|c|c|}
\hline Sample & Provenience & ${ }^{14} \mathrm{C}$ Age & $\begin{array}{c}\text { Probability } \\
\text { Distribution } 95.4 \%\end{array}$ & Relative \% \\
\hline NZA 10990 & $\begin{array}{l}\text { trench 1, layer } 15 \text { (floor } \\
\text { assoc. with stone building) }\end{array}$ & $2546 \pm 70$ b.p. & $\begin{array}{l}820-480 \text { B.C. } \\
470-410 \text { B.C. }\end{array}$ & $\begin{array}{l}88.9 \% \\
6.5 \%\end{array}$ \\
\hline Beta 129791 & $\begin{array}{l}\text { trench } 1 \text { (charcoal-rich } \\
\text { layer below stone building) }\end{array}$ & $2660 \pm 40$ b.p & 900-790 B.C. & $95.4 \%$ \\
\hline OZF 088 & trench 3 , locus 3100 & $2569 \pm 36$ b.p. & $\begin{array}{l}820-750 \text { B.C. } \\
700-540 \text { B.C. }\end{array}$ & $\begin{array}{l}53.8 \% \\
41.6 \%\end{array}$ \\
\hline OZF 090 & trench 3 , locus 3105 & $2690 \pm 33$ b.p. & 905-800 B.C. & $95.4 \%$ \\
\hline OZF 091 & trench 3 , locus 3106 & $2577 \pm 38$ b.p. & $\begin{array}{l}830-750 \text { B.C. } \\
700-540 \text { B.C. }\end{array}$ & $\begin{array}{l}58.9 \% \\
36.5 \%\end{array}$ \\
\hline OZF 092 & trench 3 , locus 3112 & $2710 \pm 31$ b.p. & 920-800 B.C. & $95.4 \%$ \\
\hline
\end{tabular}

Table 4. Radiocarbon Dates for Bannu Black-on-Red Ware from HBZD, Akra

\begin{tabular}{lcccc}
\hline Sample & Provenience & ${ }^{14} \mathrm{C}$ Age & $\begin{array}{c}\text { Probability } \\
\text { Distribution } 95.4 \%\end{array}$ & Relative $\%$ \\
\hline \multirow{2}{*}{ OZF 093} & locus 4078 & $2491 \pm 112$ b.p. & $900-350$ B.C. & $95.4 \%$ \\
OZF 094 & locus 4074 & $2564 \pm 36$ b.p & $820-750$ B.C. & $48.5 \%$ \\
& & & $7100-540$ B.C. & $46.9 \%$ \\
\hline
\end{tabular}

been extended during the Achaemenid period because of the security brought about by empire, the desire for foreign or foreign-emulation goods must, in the first instance, be explained as a reflection of changing social configurations during this time. Most of the ceramics from Akra that are paralleled in the west are highly burnished drinking bowls or tulip cups. Not only may these copy metal vessels but, as Dusinberre argued in her recent paper on Achaemenid bowls in Sardis, the presence of such vessels may indicate the emulation of banqueting and feasting practices that were a powerful symbol of authority in the Achaemenid center. ${ }^{168}$ Such practices would make an ideal political strategy to balance imperial demands for ideological conformity while legitimizing indigenous authority in an outlying satrapy. Sadly, the architectural remains from Akra do not permit us to provide more contextual information on where these vessels were recovered, and we have yet to complete a program of composi-

\footnotetext{
${ }^{168}$ Dusinberre 1999, 73-102.
}

tional analysis that indicates where they were made. Nonetheless, we would default to the argument that such vessels are not evidence for the presence of Persians per se but rather potentially indicate shifts in social and political structure brought around by changing geopolitical circumstance.

To Wheeler and other scholars, any economic and social change in South Asia was, fundamentally, the result of a west-to-east movement. However, to the east of Bannu lies the Punjab and, across the Indo-Gangetic Plains, the mighty Ganges. The question of the emergence of large, urban cities in the Ganges doab and their effects on regions to the northwest has remained largely unaddressed. The chronology of large cities like Ujjain (see fig. 2), Kausambi, Mathura, Hastinapura, Atranjikhera, and others remains tied to the vexatious question of the dating of painted gray ware ${ }^{169}$ and northern black polished ware, a ceramic that Wheeler initially dated to the fifth century B.C. because it was found

\footnotetext{
${ }^{169}$ Magee 2005, 37-44.
} 
with iron, which he believed erroneously to have been introduced by the Achaemenids. ${ }^{170}$ Recent excavations at Gotihawa in Nepal have suggested, however, an earlier dating of this ceramic assemblage and, by inference, opened the possibility that many of the Gangetic cities may date earlier than 500 B.C. ${ }^{171}$ The presence at Akra of carnelian (almost certainly from Gujarat), a small number of sherds of northern black polished ware, and figurine fragments that find ready parallels in northern India indicate that Gangetic cities might have played an economic role in developments outside the doab just as they did only centuries later with the emergence of the Mauryan empire. The assumptions of Wheeler and others concerning the primal agency of "the West" has for too long, therefore, prevented a more nuanced approach that emphasizes this region as not simply on the periphery of western-based empires but part of a larger mosaic of interaction that linked South, Central, and western Asia.

\section{CONCLUSION}

On the basis of our present work, it is clear that Akra is a key site for understanding the Late Prehistoric and Early Historic periods in the Asian subcontinent. At the least, the site unequivocally attests to processes of settlement and economic growth that are not the result of foreign annexation and control. Our excavations and survey have, however, only touched upon the many facets of human occupation in this region. There are many outstanding research issues that will guide our future work at Akra. Excavations in area A will hopefully provide data on the Bannu region during the existence of the various states and empires that held sway after the conquests of Alexander the Great in the fourth century B.C. Examination of the pre-Iron Age levels, if they can be located, will also yield data on how the Bannu region reacted to the fundamental changes that were occurring throughout South and Central Asia during the late third and early second millennium B.C. We look forward to the day when it will be possible to return to Bannu, recommence collaboration with our Pakistani colleagues, and continue our research.

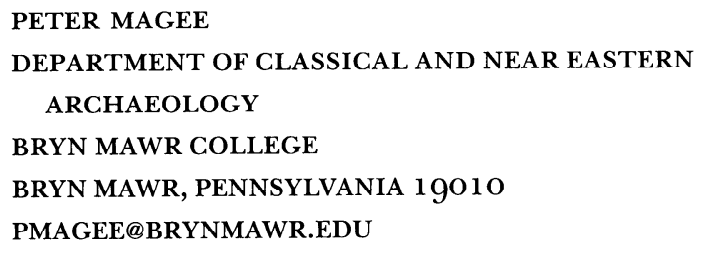

${ }^{170}$ Wheeler 1962, 43-4.

\section{GAMERON PETRIE}

DEPARTMENT OF ARCHAEOLOGY

UNIVERSITY OF GAMBRIDGE

CAMBRIDGE

UNITED KINGDOM

ROBERT KNOX

DEPARTMENT OF ASIA

BRITISH MUSEUM

LONDON

UNITED KINGDOM

RKNOX@THEBRITISHMUSEUM.AC.UK

FARID KHAN

PAKISTAN HERITAGE SOCIETY

PESHAWAR

PAKISTAN

KEN THOMAS

INSTITUTE OF ARCHAEOLOGY

UNIVERSITY COLLEGE LONDON

LONDON

UNITED KINGDOM

K.THOMAS@UCL.AC.UK

\section{Works Cited}

Ali, T., R. Coningham, M. Ali-Durrani, and G.R. Khan. 1998. "Preliminary Report of Two Seasons of Archaeological Investigations at the Bala Hissar of Charsadda, NWFP, Pakistan." Ancient Pakistan 12:1-34.

Allchin, F.R. 1995. "Early Cities and States Beyond the Ganges Valley." In The Archaeology of Early Historic South Asia, edited by F.R. Allchin, 123-51. Cambridge: Cambridge University Press.

Biscione, R. 1981. "Centre and Periphery in Late Protohistoric Turan.” In South Asian Archaeology 1979: Proceedings from the Fifth International Conference of the Association of South Asian Archaeologists in Western Europe Held in the Museum für Indische Kunst der Staalichen Museen Preussischer Kulturbesitz Berlin, edited by $\mathrm{H}$. Härtel, 203-13. Berlin: Dietrich Reimer Verlag.

Bivar, A.D.H. 1988. "The Indus Lands." In The Cambridge Ancient History 4. Cambridge: Cambridge University Press.

Boast, R. 2002. "Mortimer Wheeler's Science of Order: The Tradition of Accuracy at Arikamedu." Antiquity 76(291):165-70.

Bosworth, A.B. 1995. A Historical Commentary on Arrian's History of Alexander. Vol. 2. Oxford: Clarendon Press.

Boucharlat, R., and P. Lombard. 1985. "The Oasis of alAin in the Iron Age. Excavations at Rumeilah 19811983." Archaeology in the United Arab Emirates 4:44-73.

Briant, P. 2002. From Cyrus to Alexander: A History of the Persian Empire, translated by P.T. Daniels. Winona Lake, Ind.: Eisenbrauns.

\footnotetext{
${ }^{171}$ Verardi 2002.
} 
Brunt, P.A., trans. 2000. Anabasis Alexandri Books V-VII and Indica, by Arrian. Cambridge, Mass.: Harvard University Press.

- , trans. 2004. Anabasis Alexandri Books I-IV, by Arrian. Loeb Classical Library editions. Cambridge, Mass.: Harvard University Press.

Callieri, P. 1990. "Archaeological Activities at Bir-Kotghwandai, Swat: A Contribution of the Study of the Pottery of Early Historic Age from the NWFP." In South Asian Archaeology 1987: Proceedings of the Ninth International Conference of the Association of South Asia Archaeologists in Western Europe Held in the Fondazione Giorgio Cini, Island of San Giorgio Maggiore, Venice, edited by M. Taddei and P. Callieri, 675-92. Rome: Istituto Italiano per il Medio ed Estremo Oriente.

Callieri, P., A. Filigenzi, and G. Stacul. 1990. "Excavation at Bir-kot-ghwandat, Swat: 1987.” Pakistan Archaeology 25:163-92.

Callieri, P., P. Brocato, A. Filigenzi, M. Nascari, and L.M. Olivieri. 1992. Bir-kot-ghwanfai 1990-1992. A Preliminary Report on the Excavations of the Italian Archaeological Mission, IsMEO. Naples: Istituto Italiano per il Medio ed Estremo Oriente.

Carter, E. 1994. "Bridging the Gap Between the Elamites and the Persians in Southeastern Khuzistan." In Achaemenid History 8. Continuity and Change, edited by H. Sancisi-Weerdenburg, 65-95. Leiden: Nederlands Instituut voor het Nabije Oosten.

Casal, J.-M. 1961. Fouilles de Mundigak. Vol. 1, Texte. Vol. 2, Figures et Planches. Memoires de la Delegation Archeologique Francaise en Afghanistan. Paris: Librairie C. Klincksieck.

Chakrabati, D.K. 1997. Colonial Indology. Sociopolitics of the Ancient Indian Past. Delhi: Munshiram Manoharlal.

Coningham, R.A.E. 1995. "Dark Age or Continuum? An Archaeological Analysis of the Second Emergence of Urbanism in South Asia." In The Archaeology of Early Historic South Asia, edited by F.R. Allchin, 20-30. Cambridgc: Cambridge University Press.

Costin, C.I., T.K. Earle, B. Owen, and G. Russel. 1989. "The Impact of Inca Conquest on Local Technology in the Upper Mantaro Valley, Peru." In What's New? A Closer Look at Innovation, edited by S.E. van der Leeuw and R. Torrence, 107-39. London: Unwin Hyman.

Cribb, J. 1985. "Dating India's Earliest Coins." In South Asian Archaeology 1983: Proceedings from the Seventh International Conference of the Association of South Asian Archaeologists in Western Europe Held in the Musées Royaux d'art et d'histoire, Brussels, edited by J. Schotsmans and M. Taddei, 535-54. Naples: Istituto Universario Orientale.

Cunningham, A. 1871. Archaeological Survey of India Annual Report 2:1863-4.

Dales, G.F. 1977. New Excavations at Nad-I Ali (Sorkh Dagh), Afghanistan, Research Monograph 16. Berkeley: University of California Centre for South Asian Studies.

$\rightarrow$ D'Altroy, T.N., and R.A. Bishop. 1990. "The Provincial Organization of Inka Ceramic Production." American Antiquity 55:120-38.

Dani, A.H. 1967. "Timargarha and the Gandharan Grave Culture." Ancient Pakistan 3:22-90. . 1968. "Progress of Archaeology at the University of Peshawar." Pakistan Archaeology 5:250-64.

. 1971. "Excavations in the Gomal Valley." Ancient Pakistan 5:1-77.
Dc Miroschedji, P., N. Desse-Berset, and M. Kervran. 1987. "Fouilles du Chantier Ville Royale II a Suse (1975-1977). 2. Niveaux d'époque Achéménide, Séleicide, Parthe et Islamique." Cahiers de la Délégation Archéologie Française en Iran 15:11-133.

Dittmann, R. 1984. "Problems in the Identification of an Achaemenid and Mauryan Horizon." Archaeologische Mitteilungen aus Iran 17:155-93.

Dusinberre, E.R.M. 1999. "Satrapal Sardis: Achaemenid Bowls in an Achaemenid Capital.” AJA 103(1):73-102.

Edwardes, H.B. 1851. A Year on the Punjab Frontier in 1848-49. London: R. Bentley.

Enault, J.-F. 1979. Fouilles de Pirak. Vol. 2, Étude architecturale et figures. Fouilles de Pakistan 2. Paris: Diffusion de Boccard.

Filigenzi, A., and G. Stacul. 1985. "Excavations at Bir-kot Ghwandai." East and West 35(4):430-9.

Fleming, D. 1982. "Achaemenid Sattagydia and the Geography of Vivana's Campaign (DB III, 54-75)." Journal of the Royal Asiatic Society 2:102-22.

Francfort, H.P. 1988. "Central Asia and Eastern Iran." The Cambridge Ancient History 4. Cambridge: Cambridge University Press.

Gordon, D.H. 1943. "Early Indian Terracottas." Journal of the Indian Society of Oriental Art 9:136-95.

Hachmann, R. 1997. "Die Völkerschaften auf den Bildwerken von Persepolis." In Beiträge zur Kultutgeschichte Vorderasiens. Festschrift für Rainer Michael Boehmer, edited by U. Finkbeiner, R. Dittmann, and U. Hauptmann, 195-224. Mainz: Phillip van Zabern.

Hallock, R.T. 1969. Persepolis Fortification Tablets. Oriental Institute Publications 92. Chicago: University of Chicago Press.

Hansman, J. 1979. “An Achaemenian Stronghold.” Acta Iranica 6:289-309.

$\rightarrow$ Hastorf, C. 1990. "The Effect of the Inka State on Sausa Agricultural Production and Crop Consumption." American Antiquity 55:262-90.

Hclms, S.W. 1997. Excavations at Old Kandahar in Afghanistan 1976-1978: Conducted on Behalf of the Society for South Asian Studies (Society for Afghan Studies), Stratigraphy, Pottery and Other Finds. BAR 686. Oxford: Archaeopress.

Hemphill, W.R., and A.H. Kidwai. 1973. Stratigraphy of the Bannu and Dera Ismail Khan Areas, Pakislan, Geological Investigation in Pakistan - Geological Survey. Professional Paper 716-B. Quetta: Pakistan Geological Survey.

Hiebert, F. 1994. "Origins of the Bronze Age Oasis Civilization in Central Asia." BASPR 42. Cambridge: Peabody Museum Press

Højlund, F., and H.H. Andersen. 1994. Qala'at al-Bahrain. Vol. 1, The Northern City Wall and the Islamic Fortress. Højbjerg: Carlsberg Foundation Gulf Project, Jutland Archaeological Society.

Jarrige, J.-F., and M. Usman Hassan. 1989. "Funerary Complexes in Baluchistan at the End of the Third Millennium in the Light of Recent Discoveries at Mehrgarh and Quetta." In South Asian Archaeology 1985: Proceedings from the Eighth International Conference of South Asian Archaeologists in Western Europe Held at Moesgaard Museum, Denmark, 1-5 July 1985, edited by K. Frifelt and P. Sorensen, 150-66. London: Curzon Press.

Jarrige, J.-F., and M. Santoni. 1979. Fouilles de Pirak. Vol. 1, Texte. Fouilles de Pakistan 2. Paris: Diffusion de Boccard. 
Jones, H.J., trans. 1976. The Geography of Strabo. Loeb Classical Library edition. Cambridge: Harvard University Press.

Kent, R.G. 1953. Old Persian: Grammar, Texts, Lexicon. New Haven: American Oriental Society.

Khan, F. 1986. "Archaeological Sites in the Bannu Basin." In Lewan and the Bannu Basin: Excavation and Survey of Sites and Environments in North West Pakistan, edited by F.R. Allchin, B. Allchin, F.A. Durrani, and F. Khan, 183-95. BAR310. Oxford: British Archaeological Reports

Khan, F., J.R. Knox, and K.D. Thomas. 1986. "Sheri Khan Tarakai: A New Site in the North West Frontier Province of Pakistan." Journal of Central Asia 9:83-90.

. 1987. "The Bannu Archaeological Project: A Study of Prehistoric Settlement in Bannu District, Pakistan." South Asian Studies 3:83-90.

- 1988. "Prehistoric and Protohistoric Settlements in Bannu District." Pakistan Archaeology 23:99-148. 1989. "New Perspectives on Early Settlement in Bannu District, Pakistan.” In South Asian Archaeology 1985: Proceedings from the Eighth Intermational Conference of South Asian Archaeologists in Western Europe Held at Moesgaard Museum, Denmark, 1-5 July 1985, edited by K. Frifelt and P. Sorensen, 281-91. London: Curzon Press.

1990. "The Bannu Archaeological Project: Investigations at Sheri Khan Tarakai 1987-1989." South Asian Studies 6:241-7.

1991a. Explorations and Excavations in Bannu District, North-West Frontier Province, Pakistan, 1985-1988. British Museum Occasional Paper no. 80. London: Department of Oriental Antiquities.

. 1991b. "Sheri Khan Tarakai: A Neolithic Village in Bannu District, NWFP." In South Asian Archaeology 1987: Proceedings of the Ninth International Conference of the Association of South Asia Archaeologists in Western Europe Held in the Fondazione Giorgio Cini, Island of San Giorgio Maggiore, Venice, edited by M. Taddei and P. Callieri, 111-27. Rome: Istituto Italiano per il Medio ed Fstremo Oriente.

. 1991c. "Tradition, Identity and Individuality: Exploring the Cultural Relationships of Sheri Khan Tarakai." Pakistan Archaeology 26:156-74.

. 2000a. "Ter Kala Dheri: The Site, Excavations, Artifacts and Chronology." In Akra: The Ancient Capital of Bannu, North West Frontier Province, Pakistan, edited by F. Khan et al., 81-100. Islamabad: Taxila Institute of Asian Civilisations.

. 2000b. "The Bannu Archaeological Project: Archaeological Explorations and Excavations in Bannu Division, North-West Frontier Province, Pakistan, 1985-2000." Journal of Asian Civilisations 23(2):1-6.

Khan, F., J.R. Knox, P. Magee, C.A. Petrie, and K.D. Thomas. 2000c. "Preliminary Report on the Fourth Season of Excavation at Akra, North-West Frontier Province, Pakistan." Journal of Asian Civilisations 23(2):105-36.

Khan, F., J.R. Knox, P.G. Magee, and K.D. Thomas, with a contribution by C.A. Petrie. $2000 \mathrm{~d}$. Akra: The Ancient Capital of Bannu, North West Frontier Province, Pakistan. Islamabad: Taxila Institute of Asian Civilisations.

Knox, R. 1994. "A New Indus Cylinder Seal.” In South Asian Archaeology 1993: Proceedings of the 12th International Conference of the European Association of South Asian
Archaeologists Held in Helsinki University 5-9 July 1993, edited Asko Parpola and Petteri Koskikallio, 1-10. Helsinki: Suomalainen Tiedeakatemia.

Lambert, W.G. 1986. "Seals from West Central Asia and Adjacent Regions.” Archaeologische Mitteilungen aus Iran 19:33-40.

Lecoq, P. 1997. Les inscriptions de la Perse achéménide. Paris: Gallimard.

Liu, X. 1994. Ancient India and Ancient China: Trade and Religious Exchanges, A.I. 1-600. New York: Oxford University Press.

Magee, P. 1995. "Cultural Change, Variability and Settlement in Southeastern Arabia." Ph.D. diss., University of Sydney.

1996. "The Chronology of the Southeast Arabian Iron Age." Arabian Archaeology and Epigraphy $7: 240-52$.

. 2004. The Iron Age Settlement at Tepe Yahya. American School of Prehistoric Research Bulletin. Cambridge: Peabody Museum Press.

- 2005. "Mind the Gap: The Chronology of Painted Grey Ware and the Prelude to Early Historic Urbanism in Northern South Asia." South Asian Studies 20:37-44.

Marshall, J. 1904. "Excavations at Charsadda." Annual Report of the Archaeological Survey of India 1904:176-80.

Masimov, I.S. 1981. "The Study of Bronze Age Sites in the Lower Murghab." In The Bronze Age Civilisation of Central Asia: Recent Soviet Discoveries, by P. Kohl, 194220. New York: M.E. Sharpe.

Masson, V.M. 1959. Drevnezemledel'cheskaia kul'tura Margiany. Moscow: Izd-vo Akademii nauk SSR.

McNicoll, A.W., and W. Ball. 1996. Excavations at Kandahar 1974 and 1975: The First Two Seasons at Shahr-I Kohna (Old Kandahar) Conducted by the British Institute of Afghan Studies. BAR 641. Oxford: Tempvs Reparatvm.

$\rightarrow$ Morrison, K.D., and C.M. Sinopoli. 1992. "Economic Diversity and Integration in a Pre-Colonial Indian Empire." World Archaeology 23:335-52.

Olivieri, L.M. 1996. "Notes on the Problematical Sequence of Alexander's Itinerary in Swat: A Geo-Historical Approach." East and West 46(1-2):45-78.

Overlaet, B. 1997. "A Report on the 1952 and 1954/5 Soundings at Tall-i Taimuran (Fars)." Iranica Antiqua 32:1-51.

Petrie, C.A. Forthcoming a. "The Late 1st and Early 2nd Millennia A.D. at Akra, N.W.F.P., Pakistan.” In South Asian Archaeology 2001: Proceedings of the 16th Intermational Conference on South Asian Archaeology, European Association of South Asian Archaeologists, Paris, 2-6 July 2001, edited by C. Jarrige and V. Lefévre. Paris: Musee Guimet.

. Forthcoming b. "Ceramic Production and Distribution in the Late 1st and Early 2nd Millennia AD: Akra, Bannu Basin, NWFP Pakistan." In South Asian Archaeology 2003: Proceedings of the 17th International Conference on South Asian Archaeology, European Association of South Asian Archaeologists, Bonn, 7-11 July 2003, edited by U. Franke-Vogt. Bonn: KAVA.

Petrie, C.A., A. Askari Chaverdi, and M. Seyedin. Forthcoming. "Chapter 5: Tol-e Spid." In The Mamasani Project: A Report on Two Seasons of Excavation in 2003 by the ICAR-University of Sydney Joint Archaeological Expedition to Tol-e Nurabad and Tol-e Spid and on Two Seasons of Survey in the Rustam 1 and 2 Plains, Fars, Fars Prov- 
ince, Iran, edited by D.T. Potts and K. Roustaei. Tehran: Iranian Centre for Archaeological Research Publications.

Potts, D.T. Forthcoming. "Cyrus the Great and the Kingdom of Anshan." In The Idea of Iran: From Eurasian Steppe to Persian Empire, edited by V. Curtis. London: I.B. Tauris.

Rackham, H., trans. 1989. Natural History Books III-VII, by Pliny. Loeb Classical Library edition. Cambridge: Harvard University Press.

Raverty, H.G. 1883. Notes on Afghanistan and Parts of Beluchistan, Geographical, Ethnographical, and Historical. London: Eyre and Spottiswoode. Reprint, Quetta: Nisa Traders, 1982.

Roaf, M. 1974. "The Subject Peoples on the Base of the Statue of Darius." Cahiers de la Délégation Archéologie Française en Iran 4:73-160.

. 1983. "Sculptures and Sculptors at Persepolis." Iran 21:1-164.

Rolfe, J.C., trans. 1976. The History of Alexander, by Quintus Curtius Rufus. Loeb Classical Library edition. Cambridge: Harvard University Press.

Salvatori, G. 1975. "Analysis of the Association of Types in the Protohistoric Graveyards of the Swat Valley (Loebanr I, Katelai I, Butkara II)." East and West 25:333-51.

Sancisi-Weerdenburg, H. 1990. "The Quest for an Elusive Empire." In Achaemenid History. Vol. 4, Centre and Periphery. Proceedings of the Groningen 1986 Achaemenid History Workshop, edited by H. Sancisi-Weerdenburg and A. Kuhrt, 263-74. Leiden: Nederlands Instituut voor het Nabije Oosten.

Sancisi-Weerdenburg, H., and A. Kuhrt, eds. 1991. Achaemenid History. 6, Asia Minor and Egypt: Old Cultures in a New Empire: Proceedings of the Groningen 1988 Achaemenid History Workshop. Leiden: Nederlands Instituut voor het Nabije Oosten.

Santoni, M. 1984. "Sibri and the South Cemetery of Mehrgarh: Third Millennium Connections Between the Northern Kachi Plain (Pakistan) and Central Asia." In South Asian Archaeology 1981: Proceedings of the Sixth International Conference of the Association of South Asian Archaeologists in Western Europe Held in Cambridge University, 5-10 July 1981, edited by B. Allchin, 52-60. Cambridge: Cambridge University Press.

Sarianidi, V. 1981. "Seal Amulets of the Murghab Style." In The Bronze Age Civilisation of Central Asia: Recent Soviet Discoveries, edited by P.L. Kohl, 221-55. New York: M.E. Sharpe.

. 1985. "Early Iron Age Painted Ware Culture of South-Western Asia." Information Bulletin (International Association for the Study of the Cultures of Central Asia) 9:4-23.

-1989a. Khram I nekropoli Tillya Tepe. Moscow: Nauka.

-1989b. "Siro-khettskie bozhestva v BaktriiskoMargianskom panteone." Sovietskaya Arkheologiya 1989(4):17-24.

Schmidt, E.F. 1953. Persepolis 1. Structures, Reliefs, Inscriptions. Oriental Institute Publications no. 68. Chicago: University of Chicago Press.

- 1954. Persepolis 2. The Contents of the Treasury. Oriental Institute Publications 69. Chicago: University of Chicago Press.

- 1970. Persepolis 3. The Royal Tombs and Other Monu- ments. Oriental Institute Publications 70. Chicago: University of Chicago Press.

Schmidt, R. 1990. “III. Darius' Inscriptions.” Encyclopadia Iranica 4:299-305. London and New York: Routledge.

de Selincourt, A., trans. 1972. Historiae, by Herodotus. London: Penguin.

$\rightarrow$ Sinopoli, C.M. 1994. "The Archaeology of Empires." Annual Revue of Anthropology 23:159-80.

Stacul, G. 1966a. "Preliminary Report on the Pre-Buddhist Necropolises in Swat (W. Pakistan)." East and West 16:37-79.

-1966b. "Notes on the Discovery of a Necropolis near Kherai in the Gorband Valley (Swat, Pakistan)." East and West 16:261-74.

. 1967. "Excavations in a Rock Shelter near Ghaligai (Swat, Pakistan).” East and West 17:185-219.

. 1969. "Excavation near Ghaligai (1968) and Chronological Sequence of Protohistorical Cultures in the Swat Valley." East and West 19:9-43.

- 1980. "Bir-Kot-ghundai (Swat, Pakistan): 1978 Excavation Report." East and West 30:55-65.

1993. "Kalako-deray, Swat. 1989-1991 Excavation Report." East and West 43:69-94.

. 1997. "The Late Gandharan Grave Complex and the Following Stage." Paper presented at the 14th International Conference of the European Association of South Asian Archaeologists, 10 July 1997, Rome.

Stacul, G., and S. Tusa. 1977. "Report on the Excavations at Aligrama (Swat, Pakistan)." East and West 27:151-205.

Stein, M.A. 1905. Report of Archaeological Survey Work in the North-West Frontier Province and Baluchistan, for the Period from January 2nd, 1904 to March 31, 1905. Peshawar: NWFP Government Press.

1929a. An Archaeological Tour of Waziristan and Northern Baluchistan. Memoirs of the Archaeological Survey of India 37. Calcutta: Government of India Central Publication Office.

- 1929b. On Alexander's Track to the Indus: Personal Narrative of Explorations on the North-West Frontier of India. London: Macmillan and Co. Reprint, London: Phoenix Press, 2001.

Stern, E. 1982. Material Culture of the Land of the Bible in the Persian Period, 538-332 B.C. Jerusalem: Israel Exploration Society.

Stronach, D. 1972. "Une statue de Darius découverte à Suse-Description and Comment." Jourmale Asiatique 260:235-66.

1978. Pasargadae: A Report of the Excavations Conducted by the British Institute of Persian Studies from 1961 to 1963. Oxford: Clarendon Press.

Stuiver, M., P.J. Reimer, E. Bard, J.W. Beck, G.S. Burr, K.A. Hughen, B. Kromer, F.G. McCormac, J. v.d. Plicht, and M. Spurk. 1998. "INTCAL98 Radiocarbon Age Calibration, 24,000-0 cal BP.” Radiocarbon 40:1041-83.

$\rightarrow$ Summers, G.D. 1993. "Archaeological Evidence for the Achaemenid Period in Eastern Turkey." Anatolian Studies 43:85-108.

$\rightarrow$ Sumner, W.M. 1986. "Achaemenid Settlement in the Persepolis Plain." AJA 90(1):3-31.

Thomas, K.D. 1986. "Environment and Subsistence in the Bannu Basin." In Lewan and the Bannu Basin: Excavation and Survey of Sites and Environments in North West Pakistan, edited by F.R. Allchin, B. Allchin, F.A. Durrani, and M.F. Khan, 13-33. BAR-IS 310. Oxford: 
British Archaeological Reports.

Thomas, K.D., and J.R. Knox. 1994. "Routes of Passage: Later Prehistoric Settlement and Exploitation of a Frontier Region in Northwestern Pakistan.” Bulletin of the Institute of Archaeology, University College London 31:89-104.

Thomas, K.D., J.R. Knox, and F. Khan. 1997. "Technology Transfer and Culture Change: An Example from Northwest Pakistan.” In South Asian Archaeology 1995: Proceedings of the 13th Conference of the European Association of South Asian Archaeologists, Cambridge, 5-9 July 1995, edited by R. Allchin and B. Allchin, 237-51. New Delhi: Oxford University Press and IBH.

Thorburn, S.S. 1876. Bannu; or Our Afghan Frontier. London: Trübner and Co.

Tusa, S. 1979. "The Swat Valley in the 2nd and 1st Millennium B.C.: A Question of Marginality." In South Asian Archaeology 4, 2:675-90. Berlin: Dietrich Reimer.

Vallat, F. 1993. Les noms géographique des sources suso-élamites. Répertoire géographique des textes cuneiforms. Weisbaden: Reichhert.

Vats, M.S. 1940. Excavations at Harappa: Being an Account of Archaeological Excavations at Harappa Carried Out Between the Years 1920-21 and 1933-34. Delhi: Manager of Publications, The Archaeological Survey of India.

Venco Ricciardi, R. 1980. "Survey in the Upper Atrek Valley." Mesopotamia 15:51-72.

Verardi, G. 2002. Excavations at Gotihawa and a Territorial Survey in Kapilvastu District of Nepal: A Preliminary Report. Occasional Paper 2. Lumbini, Nepal: Lumbini
International Research Institute.

Vogelsang, W. 1985. "Early Historical Arochosia in Southeast Afghanistan. Meeting-Place Between East and West." Iranica Antiqua 20:55-99.

1986. "Four Short Notes on the Bisutun Text and Monument." Iranica Antiqua 21:121-40.

. 1987. "Some Remarks on Eastern Iran in the Late-Achaemenid Period." In Achaemenid History I. Sources, Structures and Synthesis, edited by H. SancisiWeerdenburg, 183-9. Leiden: Nederlands Instituut voor het Nabije Oosten.

1990. "The Achaemenids and India, in SancisiWeerdenburg." In Achaemenid History. Vol. 4, Centre and Periphery. Proceedings of the Groningen 1986 Achaemenid History Workshop, edited by H. Kuhrt and A. Kuhrt, 93-110. Leiden: Nederlands Instituut voor het Nabije Oosten.

1992. The Rise and Organisation of the Achaemenid Empire: The Eastern Iranian Evidence. Leiden: E.J. Brill.

. 1998. "Medes, Scythians and Persians: The Rise of Darius in a North-South Perspective." Iranica Antiqua 33:195-224.

Wheeler, R.E.M. 1962. Charsada: A Metropolis of the NorthWest Frontier: Being a Report on the Excavations of 1958. London: Oxford University Press.

Witzel, M. 1980. "Early Eastern Iran and the Atharva Veda." Persica 9:86-128.

Zadneprovsky, Y.A. 1962. Dreonezemledel'cheskaia kul'tura Fergany. Materialy i issledovaniia po arkheologii SSSR 118. Moscow: Izd-vo Akademii nauk SSR. 